Prepared in cooperation with the Missouri Department of Transportation

\title{
Real-Time River Channel-Bed Monitoring at the Chariton and Mississippi Rivers in Missouri, 2007-09
}
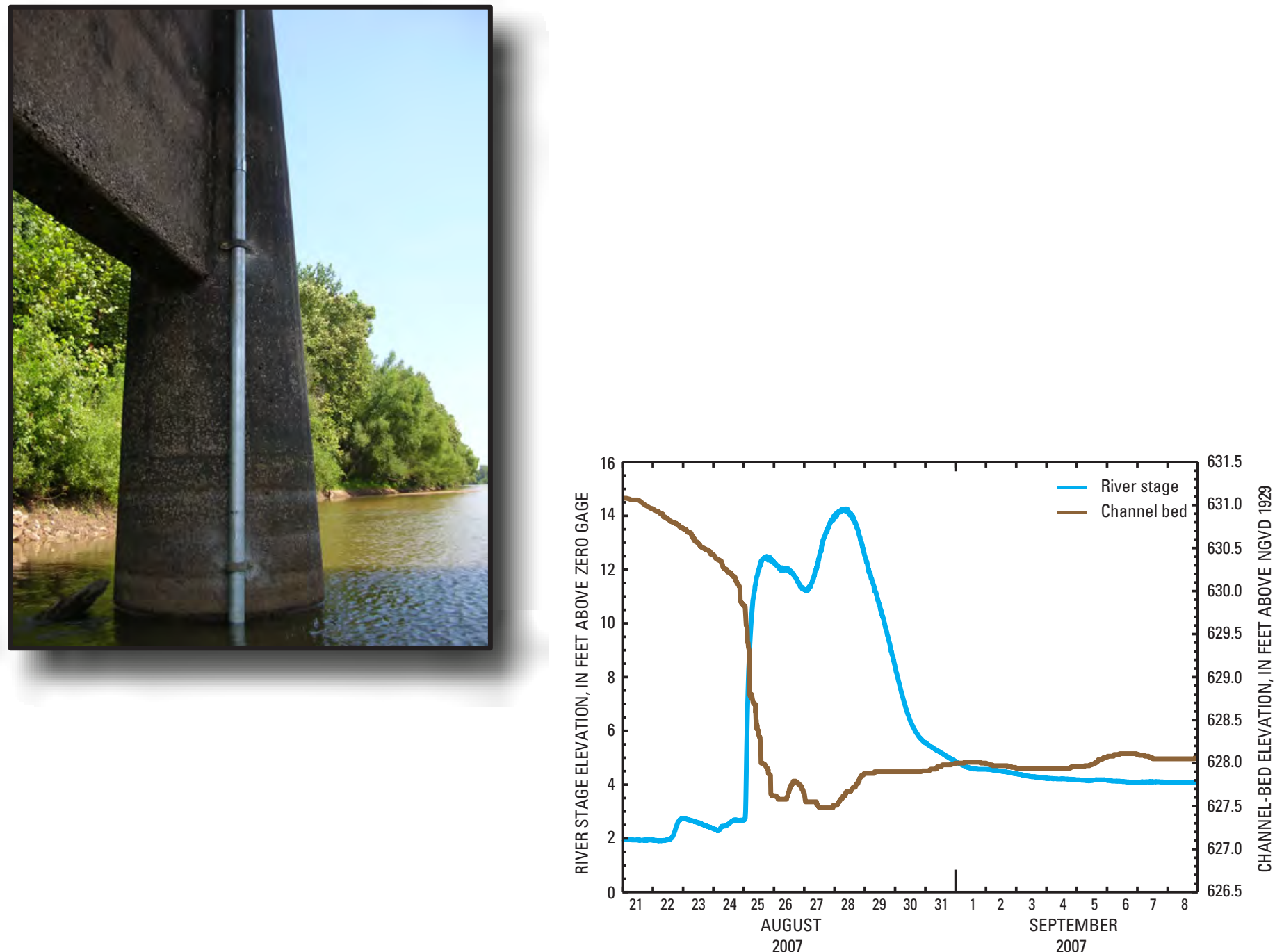

Scientific Investigations Report 2009-5254 
Cover photograph. River channel-bed monitor installation and channel-bed elevation at the downstream side of the upstream column of pier 4 and river stage from August 21 through September 9, 2007, for the Chariton River near Prairie Hill, Missouri (structure L-344). Photograph by Paul H. Rydlund, Jr., U.S. Geological Survey. 


\section{Real-Time River Channel-Bed Monitoring at the Chariton and Mississippi Rivers in Missouri, 2007-09}

By Paul H. Rydlund, Jr.

Prepared in cooperation with the Missouri Department of Transportation

Scientific Investigations Report 2009-5254 


\section{U.S. Department of the Interior \\ KEN SALAZAR, Secretary \\ U.S. Geological Survey \\ Marcia K. McNutt, Director}

\section{U.S. Geological Survey, Reston, Virginia: 2009}

For more information on the USGS - the Federal source for science about the Earth, its natural and living resources, natural hazards, and the environment, visit http://www.usgs.gov or call 1-888-ASK-USGS

For an overview of USGS information products, including maps, imagery, and publications, visit http://www.usgs.gov/pubprod

To order this and other USGS information products, visit http://store.usgs.gov

Any use of trade, product, or firm names is for descriptive purposes only and does not imply endorsement by the U.S. Government.

Although this report is in the public domain, permission must be secured from the individual copyright owners to reproduce any copyrighted materials contained within this report.

Suggested citation:

Rydlund, P.H., Jr., 2009, Real-time river channel-bed monitoring at the Chariton and Mississippi Rivers in Missouri, 2007-09: U.S. Geological Survey Scientific Investigations Report 2009-5254, 27 p. 


\section{Contents}

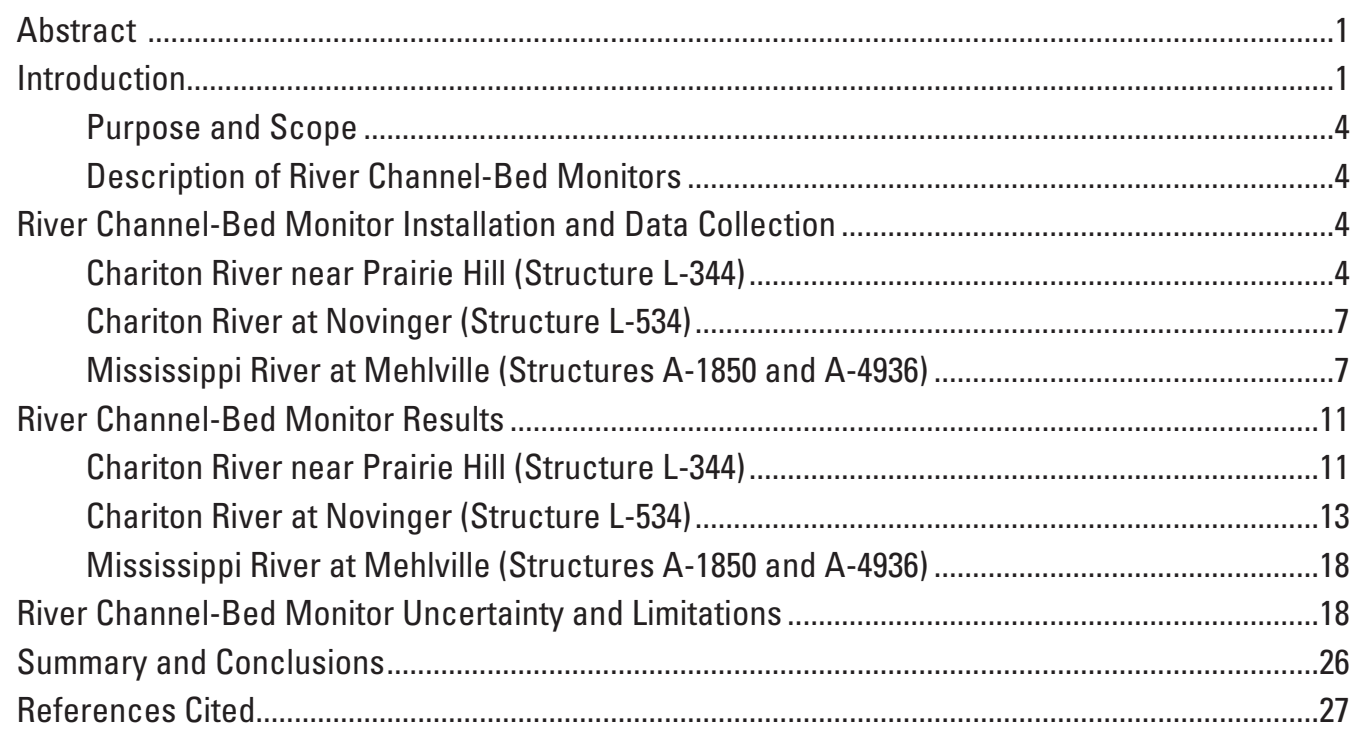

\section{Figures}

1. Map showing location of river channel-bed monitors in Missouri...................................2

2. Internal configuration, installation, and data dissemination of a river channel-bed monitor

3. Graph showing cross sections from historic flood measurements made at the downstream face of structure L-344 crossing the Chariton River near Prairie Hill, Missouri.

4. Photgraphs showing installation of a river channel-bed monitor on structure L-344 over the Chariton River near Prairie Hill, Missouri

5. Graph showing cross sections from historic flood measurements made at the downstream face of structure L-534 crossing the Chariton River at Novinger, Missouri.

6. Photgraphs showing installation of river channel-bed monitors on structure L-534 over the Chariton River at Novinger, Missouri.

7. Predicted contraction and pier scour depths based on the 1993 flood for piers 1 through 14 and river channel-bed monitor design at pier 12 at structures A-1850 and A-4936 over the Mississippi River at Mehlville.....

8. Photgraphs showing installation of river channel-bed monitors on structures

A-1850 and A-4936 over the Mississippi River at Mehlville, Missouri.

9-10. Graphs showing-

9. River channel-bed elevation at the downstream side of the upstream column of pier 4 and river stage from August 21, 2007, through August 21, 2009, for the Chariton River near Prairie Hill, Missouri (structure L-344).

10. River channel-bed elevation at the downstream side of the upstream and downstream columns of pier 7 and river stage from May 22, 2008, through August 22, 2009, for the Chariton River at Novinger, Missouri (structure L-534) ....19 
11-13. Graphs showing-

11. River channel-bed elevation at the downstream nose of pier 12 and river stage from October 24, 2008, through August 24, 2009, for the Mississippi River near Mehlville, Missouri (structures A-1850 and A-4936)...

12. River channel-bed elevation at the upstream nose of pier 12 and river stage during the period of October 24, 2008, through December 31, 2008, for the Mississippi River near Mehlville, Missouri (structures A-1850 and A-4936)

13. Bathymetric surveys conducted October 2, 2008, May 13, 2009, and July 8 , 2009, using multibeam sonar at the Mississippi River near Mehlville, Missouri (structures A-1850 and A-4936).

\section{Table}

1. Depth soundings near locations of river channel-bed monitors on the downstream side of the indicated column of bridges on the Chariton River in Missouri

\section{Conversion Factors}

Inch/Pound to SI

\begin{tabular}{lcl}
\hline \multicolumn{1}{c}{ Multiply } & By & \multicolumn{1}{c}{ To obtain } \\
\hline inch (in.) & Length & \\
inch (in.) & 2.54 & centimeter $(\mathrm{cm})$ \\
foot (ft) & 25.4 & millimeter $(\mathrm{mm})$ \\
mile (mi) & 0.3048 & meter $(\mathrm{m})$ \\
& 1.609 & kilometer $(\mathrm{km})$ \\
\hline foot per second $(\mathrm{ft} / \mathrm{s})$ & Flow rate & \\
cubic foot per second $\left(\mathrm{ft}^{3} / \mathrm{s}\right)$ & 0.3048 & meter per second $(\mathrm{m} / \mathrm{s})$ \\
hertz $(\mathrm{Hz})$ & 0.02832 & cubic meter per second $\left(\mathrm{m}^{3} / \mathrm{s}\right)$ \\
\hline
\end{tabular}

Left and right pertain to an observer facing downstream.

Vertical coordinate information is referenced and noted as either "National Geodetic Vertical Datum of 1929" (NGVD 29) or the "North American Vertical Datum of 1988" (NAVD 88).

Elevation, as used in this report, refers to the distance above the vertical datum. 


\title{
Real-Time River Channel-Bed Monitoring at the Chariton and Mississippi Rivers in Missouri, 2007-09
}

\author{
By Paul H. Rydlund, Jr.
}

\section{Abstract}

Scour and depositional responses to hydrologic events have been important to the scientific community studying sediment transport as well as potential effects on bridges and other hydraulic structures within riverine systems. A river channel-bed monitor composed of a single-beam transducer was installed on a bridge crossing the Chariton River near Prairie Hill, Missouri (structure L-344) as a pilot study to evaluate channel-bed change in response to the hydrologic condition disseminated from an existing streamgage. Initial results at this location led to additional installations in cooperation with the Missouri Department of Transportation at an upstream Chariton River streamgage location at Novinger, Missouri (structure L-534) and a Mississippi River streamgage location near Mehlville, Missouri (structures A-1850 and A-4936). In addition to stage, channel-bed elevation was collected at all locations every 15 minutes and transmitted hourly to a U.S. Geological Survey database. Bed elevation data for the Chariton River location at Novinger and the Mississippi River location near Mehlville were provided to the World Wide Web for real-time monitoring. Channelbed data from the three locations indicated responses to hydrologic events depicted in the stage record; however, notable bedforms apparent during inter-event flows also may have affected the relation of scour and deposition to known hydrologic events. Throughout data collection periods, Chariton River locations near Prairie Hill and Novinger reflected bed changes as much as 13 feet and 5 feet. Nearly all of the bed changes correlated well with the hydrographic record at these locations. The location at the Mississippi River near Mehlville indicated a much more stable channel bed throughout the data collection period. Despite missing data resulting from damage to one of the river channel-bed monitors from ice accumulation at the upstream nose of the bridge pier early in the record, the record from the downstream river channel-bed monitor demonstrated a good correlation (regardless of a 7 percent high bias) between bedform movement and the presence of bedforms surrounding the bridge as indicated by coincident bathymetric surveys using multibeam sonar.

\section{Introduction}

Channel-bed dynamics of scour and deposition are natural phenomena in alluvial systems in which bed and bank materials erode and re-deposit through the action of moving water. For a given hydrographic event, bed scouring is typically observed on the rising limb of the hydrograph. At some point beyond the peak of the hydrograph, deposition begins to occur on the receding limb. The addition of a hydraulic structure, such as a bridge, exacerbates scouring conditions due to a change in flow area and velocity. To better understand the effects of scour around bridges, classifications such as local and contraction scour (Richardson and Davis, 2001) need to be defined. The primary classification of scour associated with piers or pile bents is defined as local scour, which is the result of increased velocities caused by flow impinging on an impediment. Contraction scour, which is a result of a reduction in flow area from a bridge, may also exist at piers or pile bents as an additive effect to produce total scour.

Prior assessment methods conducted by the U.S. Geological Survey (USGS) in cooperation with the Missouri Department of Transportation (MoDOT) have been used to estimate overall scour depths in the state of Missouri since 1991 (Huizinga and Rydlund, 2004). Assessments by the USGS were conducted in three approaches: potential-scour assessment (Level 1), rapid estimation assessment (Level 1+), and a detailed hydraulic assessment (Level 2). Level 2 assessments were used to compute contraction, local, and abutment scour depths and ultimately were used to determine which bridges were scour critical and would require further monitoring or application of scour countermeasures (Richardson and Davis, 2001; Huizinga and Rydlund, 2004). As a result of these assessments conducted to determine "scour-critical" bridges, resource managers associated with the maintenance of state-owned bridges have had a need to monitor channel-bed scour in the vicinity of pier and pile bents as well as abutments at existing and newly constructed bridges.

River channel-bed monitoring historically has been conducted during pre- and post-flood conditions requiring the deployment of personnel to known scour-critical bridges. The limitation of personnel, resources, and time, make effective channel-bed monitoring before, during, and after substantial 
flood events difficult. Technological advances in sonar, coupled with the use of data collection platforms (hereinafter referred to as DCP's), satellite telemetry and dissemination through the World Wide Web (hereinafter referred to as the Web), allow channel-bed monitoring in a real-time manner. High-frequency single-beam transducers, the primary components of river channel-bed monitors (hereinafter referred to as RCBM's), provide good channel bottom definition and depth range and have been used extensively in marine environments as a reliable means of navigation. Well-protected RCBM's, installed and operated by the USGS in cooperation with MoDOT, have provided monitoring at critical locations near bridge piers for two locations on the Chariton River and one location on the Mississippi River (fig. 1) between August 20, 2007, and August 24, 2009.

The integration of an RCBM with a DCP used to record and transmit river stage at streamgages has allowed the monitoring of bed dynamics as a function of river stage (fig. 2).

On an hourly basis, the DCP transmits stage sensor and bed monitoring inputs collected every 15 minutes through a series of satellites to a USGS office where the data are automatically uploaded into the USGS National Water Information System (NWIS) database (http://waterdata.usgs.gov/nwis). Data are updated to the Web from NWIS, resulting in a total time from field transmission to Web in approximately 7 to 8 minutes (U.S. Geological Survey, 2009, fig. 2).

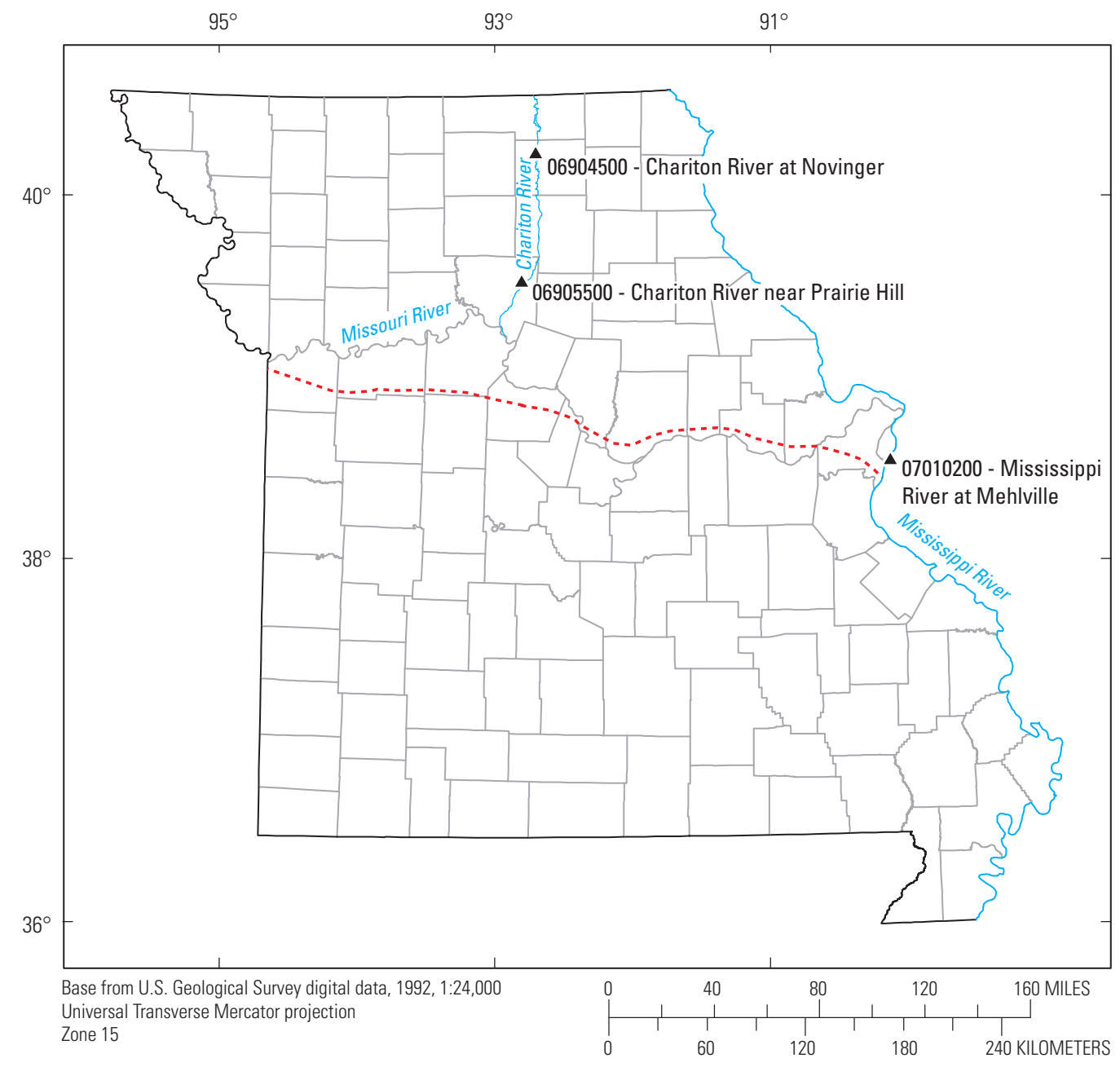

EXPLANATION

\ 06904050 Streamgage with river channel-bed monitor and station number

- - - Southern extent of glaciation (Missouri Division of Geology and Land Survey, 1979)

- Study area rivers

Figure 1. Location of river channel-bed monitors in Missouri. 


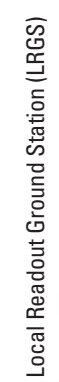
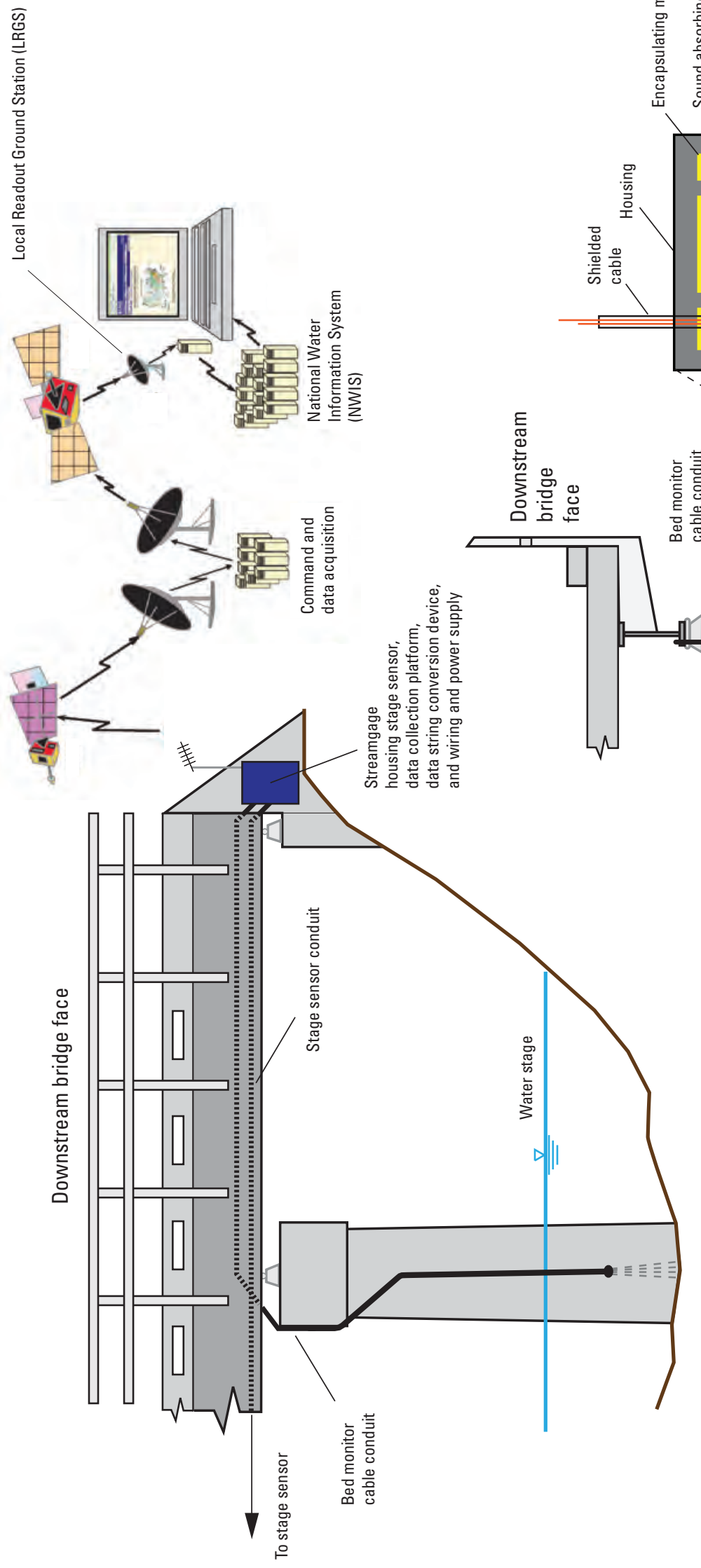

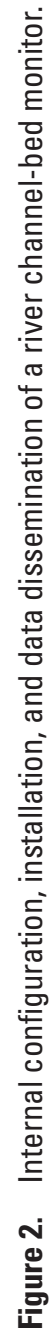




\section{Purpose and Scope}

The purpose of this report is to document RCBM installations and real-time acquisition of data during 2007-09 accessed from an internal Web link at two locations on the Chariton River and one location on the Mississippi River. This report provides a method of evaluating channel-bed elevation change throughout a hydrograph at discrete locations underneath bridges. The installation of RCBM's, integrated with existing 15-minute recording DCP's and hourly telemetry, provide a means by which to investigate the relation between scour and deposition of the channel bed hydrographically in comparison with river stage. Documentation of the scour and deposition relation illustrates overall channel-bed stability, the presence of bedforms, and an indication of bed equilibrium at the Chariton and Mississippi River locations.

\section{Description of River Channel-Bed Monitors}

The RCBM's used in this application are composed of a single-beam transducer commonly used in the light- and leisure-marine markets. The transducer utilizes Smart ${ }^{\mathrm{TM}}$ sensor technology composed of active electronics within the transducer body allowing functionality of both the transducer element and signal processor. The structure of the transducer is a piezoceramic element partially surrounded by sound-absorbing material such as cork or foam that aids in dampening unwanted vibrations. The piezoceramic element and soundabsorbing material are contained within encapsulating material composed of urethane and sealant that fills the housing. The housing is a sturdy composition of stainless steel that protects the brittle ceramic element within (Airmar Technology Corporation, 2006; fig. 2). A shielded cable enclosing conductors of electrical current is permanently attached to the transducer. RCBM's installed at the Chariton and Mississippi River locations are optimized to transmit at a frequency of 235 kilohertz with a narrow beam angle of 7 degrees through a urethane acoustic window (Airmar Technology Corporation, 2006).

To ensure data communication, a conversion device was used to convert the depth value, expressed as the National Marine Electronics Association (NMEA 0183) data string, from the RCBM's to the Serial Data Interface at 1200 Baud (SDI-12) required by the DCP. The DCP sends an address query at programmed intervals of 15 minutes to the conversion device. Once submitted, the conversion device "wakes up" from a lower-power "sleep" mode to collect NEMA 0183 depth value data from the RCBM. The data are then stored in a temporary buffer, converted to SDI-12, then sent to the DCP. The conversion device allows the user to enter an offset value when installing the RCBM and evaluating the current water depth. The DCP receives the depth value data string as SDI-12 from the conversion device and transmits it along with other resident streamgage parameters every hour by satellite telemetry to the USGS NWIS database.

\section{River Channel-Bed Monitor Installation and Data Collection}

Site selections for RCBM installations were based on known occurrences of substantial scour and deposition and locations identified as potentially scour critical from Huizinga and Rydlund (2004) in cooperation with MoDOT. Glacial till covers the majority of the landscape surrounding the Chariton and Mississippi River Basins within Missouri (Raisz, 1957; fig. 1) and is composed of a mixture of clay, sand, and gravel. Eroded glacial till sediments of sand and silt dominate channel beds within the Chariton and Mississippi River Basins, which have a short-duration scour and deposition process as velocity, bed shear stress, and sedimentation occur during rising and receding river stages (Leopold and others, 1964).

For effective monitoring of the river channel bed, installations were site-specific. The RCBM's used in this data collection effort could not receive a message sending protocol known as a "ping" less than 1.5 feet without a resonating effect of the sonar, which produced a false, secondary depth echo that would offset the actual depth of the channel bed. As a result, the installation of the RCBM had to occur in a pool with sufficient depth to provide the necessary 1.5 feet of clearance below the RCBM. In addition to depth concerns, protection from debris was needed to avoid an intermittent loss of data or damage to the RCBM. Installations at the Chariton River sites and one installation at the Mississippi River site occurred on the downstream side of columns or piers that existed within a sufficient pool to ensure protection and continual monitoring.

\section{Chariton River near Prairie Hill (Structure L-344)}

A USGS streamgage located on structure L-344 over the Chariton River near Prairie Hill (06905500) has been in operation since September 1953. Historic flood discharge measurements made with a current meter suspended above a sounding weight were used to obtain depth measurements at approximately 20 to 30 locations across the channel during each discharge measurement at the downstream face of structure L-344 (fig. 3). Historic high-flow measurements have indicated the frequent accumulation of a sizeable debris raft on the center pier, which effectively increases pier width, decreases the bridge-opening area, and ultimately contributes to scour and potential long-term degradation (Becker, 1994). Cross sections depicted in figure 3 illustrate substantial channel-bed change, indicating frequent scour and deposition, making this a good pilot study location for an RCBM.

The existing streamgage utilizes a pressure sensor that is used to collect water stage measurements. The data from an RCBM installed on the downstream side of the upstream conical column of pier bent 4 (fig. 4) was integrated with realtime disseminated parameters of the existing streamgage. A 3 -inch section of schedule 40 galvanized steel pipe was used 


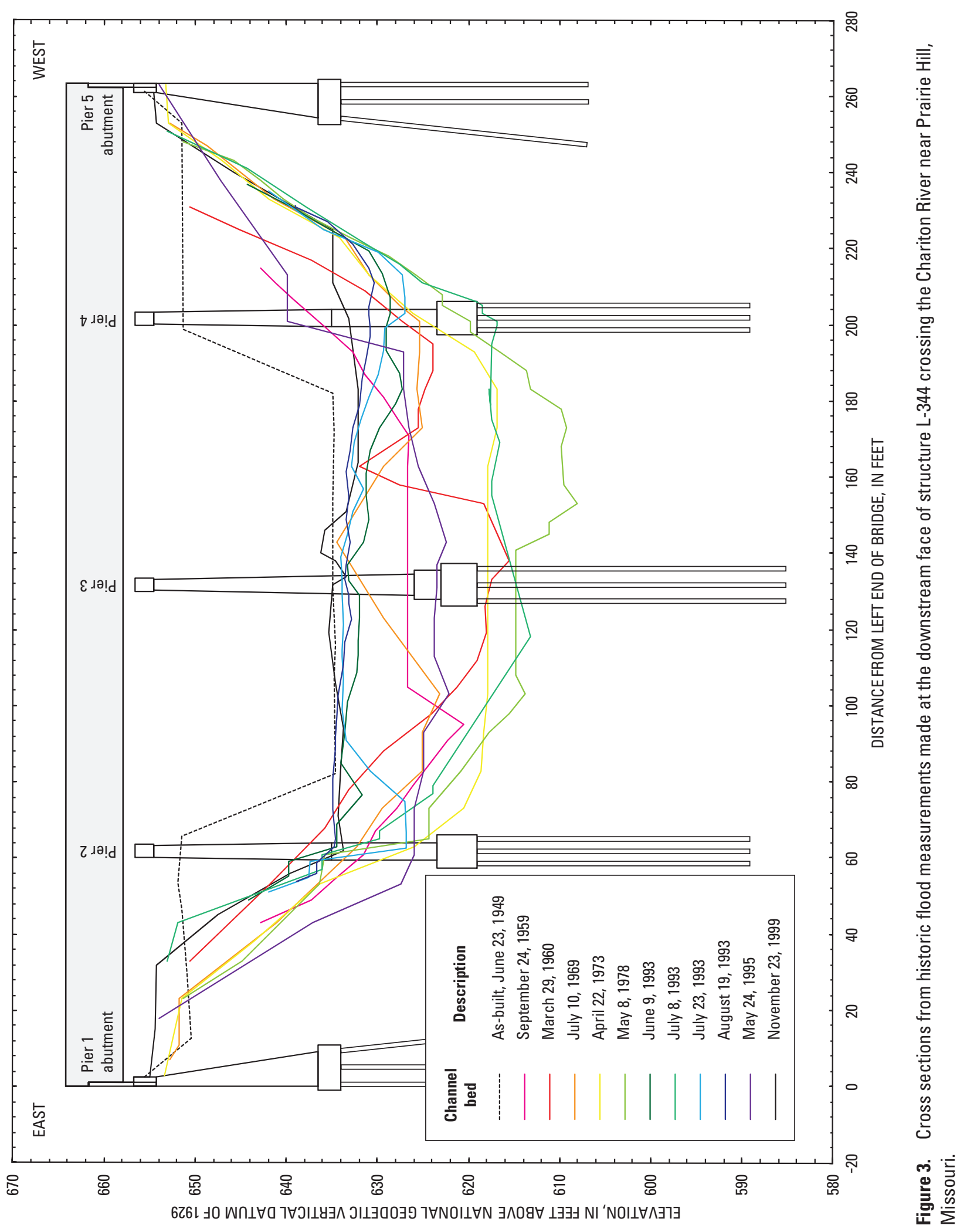




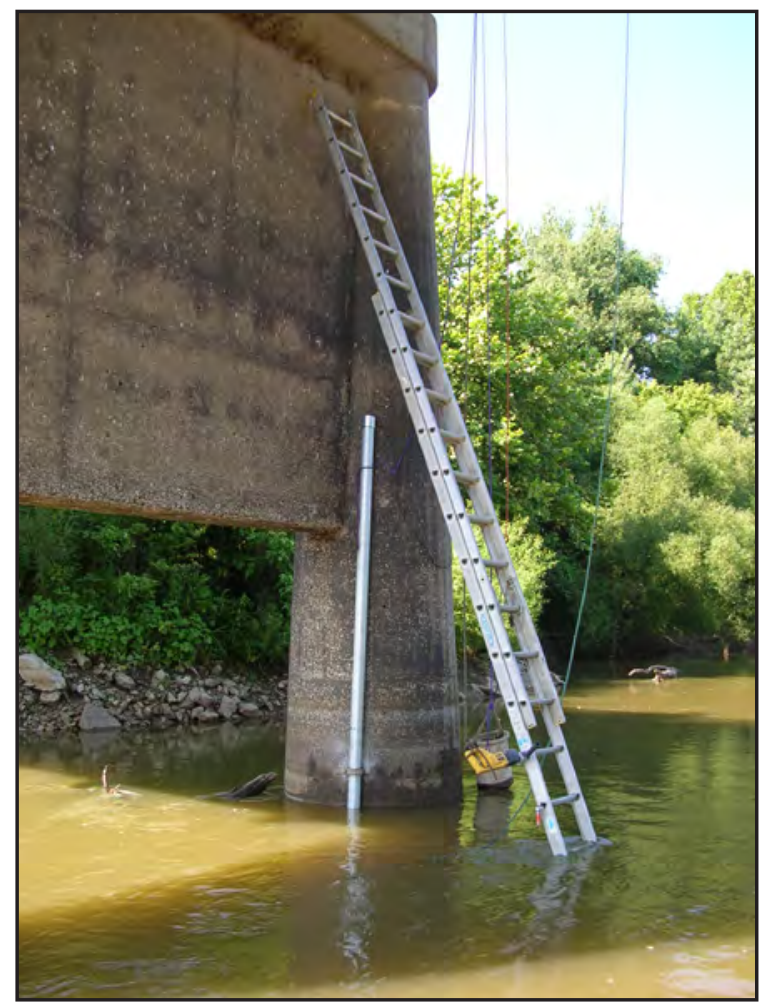

Installation of 3-inch galvanized steel pipe encasing the transducer head and shielded cable on the downstream side of the upstream conical column of pier 4 .

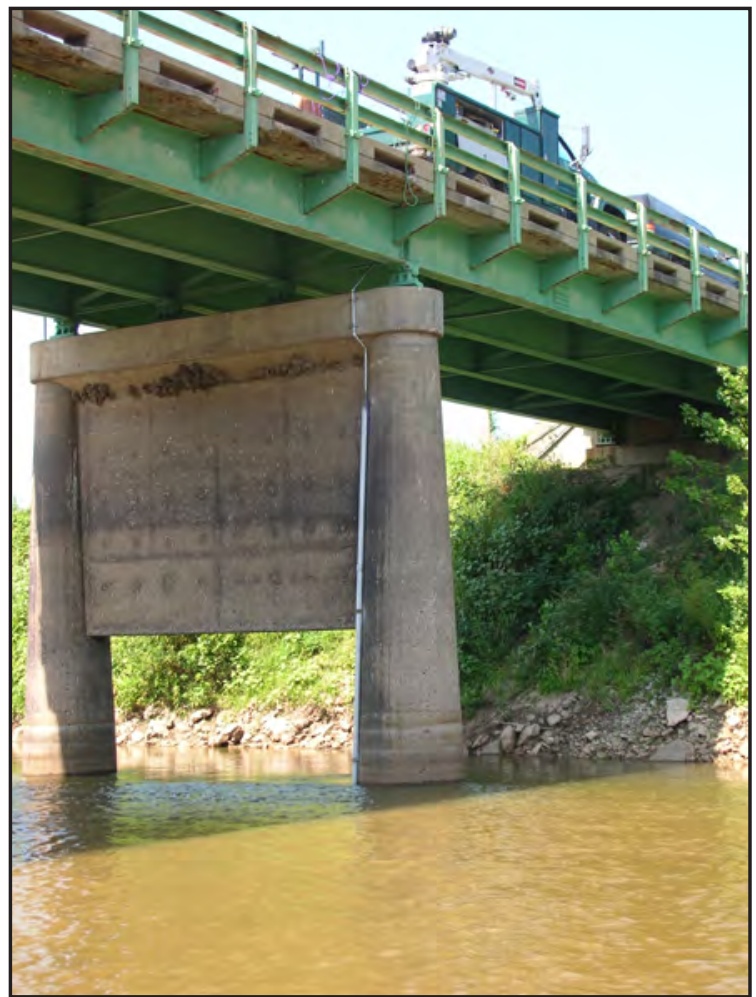

Installation of 1-inch to 3 -inch galvanized steel pipe encasing the transducer head and shielded cable on the downstream side of the upstream conical column of pier 4 and between girders.

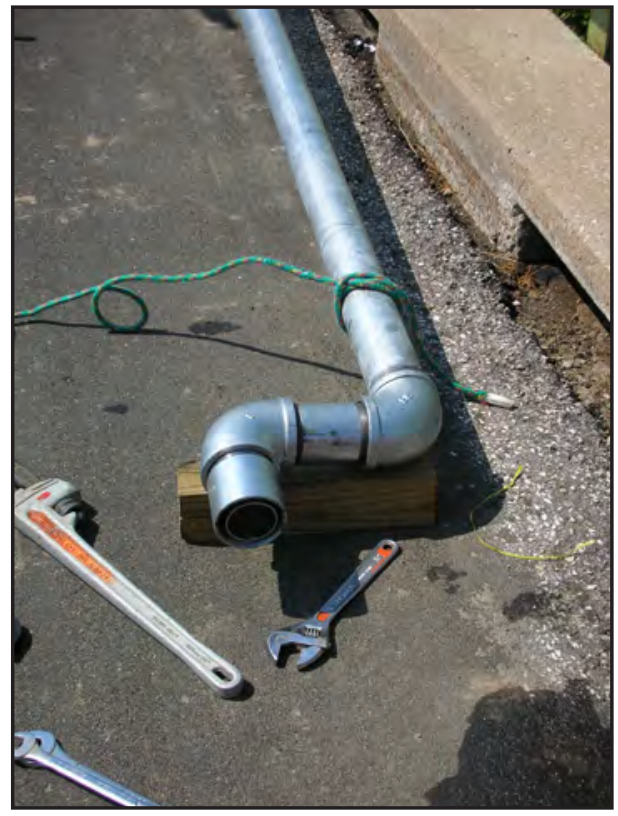

Three-inch galvanized steel pipe with offset encasing the transducer head, which is flush with pipe. Offset designed to prevent acoustic signal interference from pier and footing.

Figure 4. Installation of a river channel-bed monitor on structure L-344 over the Chariton River near Prairie Hill, Missouri. 
as conduit to protect the transducer head and shielded cable at the lower portion of the pier (fig. 4).

Schedule 40 steel pipe was used to protect the transducer head and cable from debris, in addition to providing stability and rigidity in the overall installation. Once the installation was complete, the power, data, and ground wires were connected to the NEMA 0183 to SDI-12 conversion device, which was subsequently wired to the DCP and programmed as an additional SDI-12 parameter to be received and transmitted. The initial depth measurement acquired by the data collector was checked in the field for accuracy. At this location, there was no offset that was needed. The initial and three subsequent depth measurements were verified using a measuring rod during the next hour (four 15-minute readings).

In addition to existing streamgage parameters received through a Local Readout Ground Station (LRGS), decoded 15-minute data from the RCBM were populated into a newly established data descriptor, then converted to the current streamgage datum within the USGS Automated Data Processing System (ADAPS) (Bartholoma and others, 2003). These data were not disseminated by the Web, but resided internally within the USGS to be monitored as a pilot study.

\section{Chariton River at Novinger (Structure L-534)}

Structure L-534 crossing the Chariton River at Novinger was considered to be a good location for monitoring because of a partially exposed foundation at pier 7 detected in a 1995 channel-bed survey, a non-cohesive sand channel bed, and an indication of potential pier and contraction scour during a 1995 scour assessment conducted by the USGS (Huizinga and Rydlund, 2004). A USGS streamgage (06904500) has been in operation at this location since October 1956. Historic flood discharge measurements (fig. 5) indicate a dynamic sand channel bed that has scour and deposition, and has migrated laterally as a result of a riprap blanket constructed underneath the left approach span between 1993 and 1995 based on MoDOT records (Ken Foster, Federal Highway Administration, oral commun., 2009).

Infrastructure associated with the USGS streamgage shelter was mounted on the cap at the downstream side of pier 7 , which provided accessibility for the installation of the steel pipe that houses the RCBM at the upstream and downstream side of pier 7. A section of 1-inch pipe was installed on the downstream side of the downstream conical column paralleling the existing pressure sensor conduit (fig. 6) and another section of 1-inch pipe was installed on top of the cap and on the downstream side of the upstream conical column (fig. 6). Similar to the installation on structure L-344 near Prairie Hill, a reducer allowed the transition from the 1-inch pipe to the 3-inch pipe, which ultimately housed the transducer heads below the water surface at the downstream side of the upstream and downstream columns (fig. 6). Transmitted data from this location were processed in ADAPS and disseminated through the Web.

\section{Mississippi River at Mehlville (Structures A-1850 and A-4936)}

The Mississippi River crossing near the town of Mehlville, Missouri, is better known as the Jefferson Barracks Bridge (hereinafter referred to as the JBB), which is composed of east- and west-bound structures on I-255 that span the Mississippi River south of St. Louis. The JBB was a location used for monitoring channel-bed changes resulting from the 1993 flood. Scour measurements made during the 1993 flood indicated dunes as high as 6 to 8 feet located upstream from piers 8 and 9 (Mueller and others, 1995), and a scour assessment conducted by the USGS in 2003 (Huizinga and Rydlund, 2004) for the 1993 flood indicated potential local pier scour at piers 7 through 12 (fig. 7). Installations of RCBM's at overbank piers 7 through 11 were not feasible because the pier columns are substantially recessed underneath the bridge deck and a large oblique angle is required for the transducer head to be unobstructed by the footer and seal course. The scour assessment conducted in 2003, based on the 1993 flood, predicted a larger amount of scour at overbank piers 7 through 11 (as a result of partially exposed foundations) than at navigation channel piers 12 and 13 (fig. 7). However, preliminary soundings at pier 12 identified a partially exposed foundation in 2008, which, when coupled with the feasibility of RCBM installations at the upstream and downstream nose of the pier, made this pier an acceptable location to monitor channel-bed change.

Substructure details from MoDOT bridge plans (Missouri Department of Transportation, 1977) provided the basis for an RCBM design at pier 12 (fig. 7). The complication in this design was ensuring that the acoustic signal had adequate clearance from the footer and seal course, yet minimizing the angle of the RCBM so that the signal would be returned and not reflected off the channel bottom in a direction away from the RCBM. Another concern was ensuring adequate protection to the RCBM (particularly at the upstream nose) on a large river (approximately 2,000 feet wide; Huizinga and Rydlund, 2004) with substantial hydrodynamic force and potential floating debris.

Based on the upstream and downstream protruding length of the footer and seal course from pier 12, an angle of 22 degrees was determined to provide adequate clearance to the channel bottom (fig. 7). Independent tests were conducted in the field with an RCBM positioned at a variety of vertical departures. The results of these tests showed that this angle (22 degrees) was sufficient to ensure signal return from the channel bottom without reflection from the transducer head. Proper protection of the RCBM and shielded cable was afforded by a 3-inch pipe used to encase the RCBM. The 3 -inch pipe transitioned to a 1 -inch pipe protected by 3 - by 3 -inch steel angle. The 3 - by 3 -inch angle provided protection to the location of a beveled edge (fig. 7), identified as a location of observed high water of record in MoDOT bridge plans (Missouri Department of Transportation, 1977). Above the beveled edge on the upstream and downstream nose of pier 12, polyvinylchloride (PVC) conduit was used to house the 


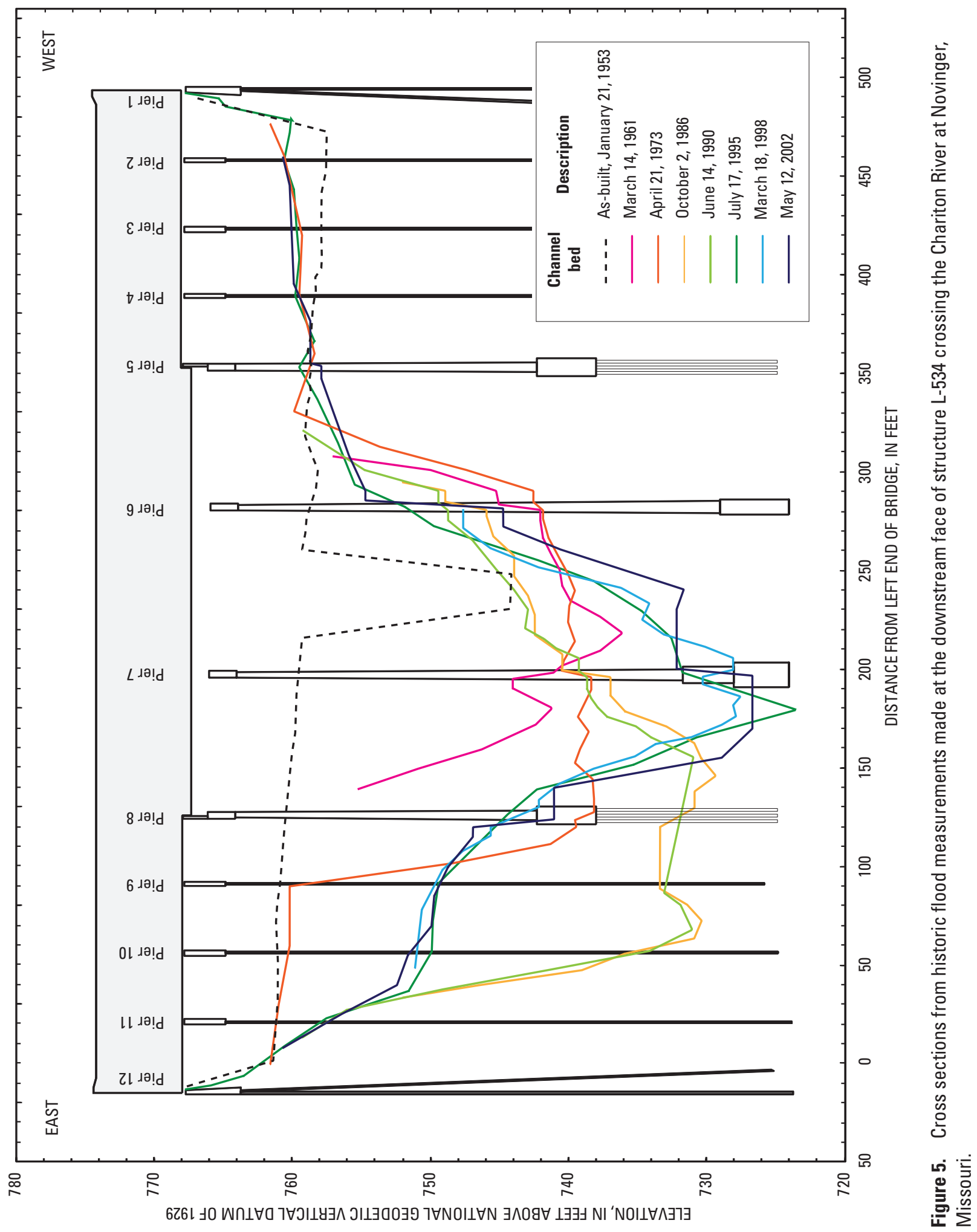




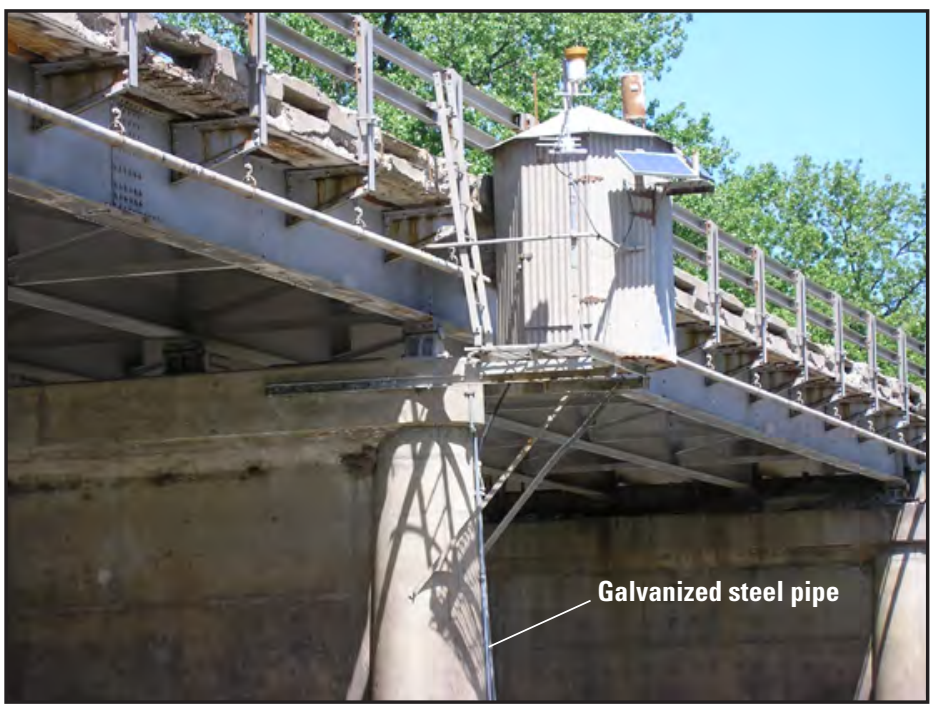

Existing streamgage shelter on the downstream side of pier 7. Note the galvanized steel pipe fastened on the conical column encasing the river channel-bed monitor shielded cable.

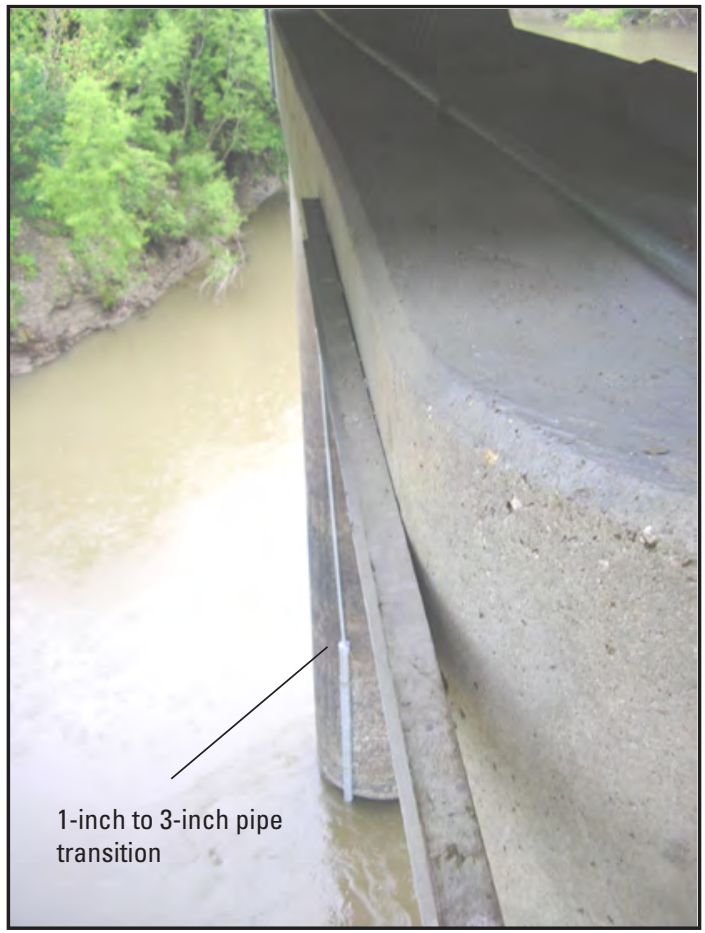

Installation of galvanized steel pipe along the top of the cap and continuing along the downstream side of the upstream conical column. Note the 1 -inch to 3 -inch pipe transition to accommodate the transducer head below the water surface.

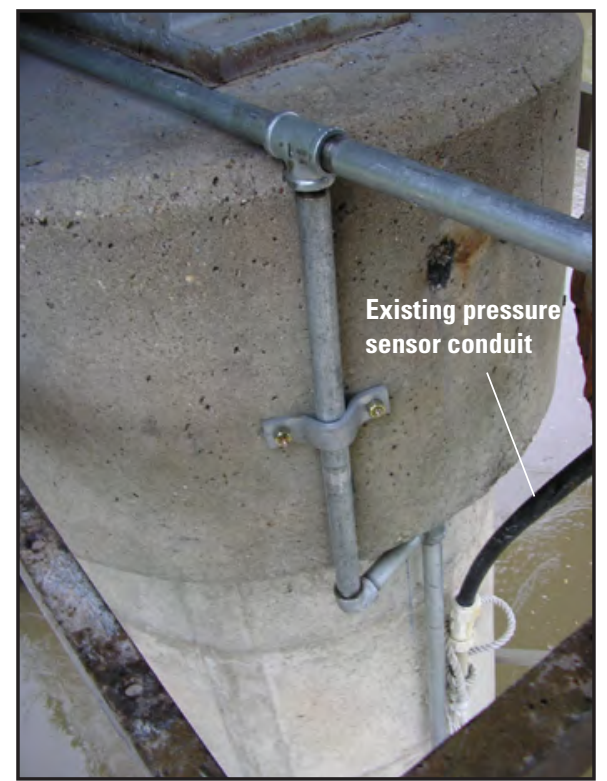

Installation of pipe junction to accommodate the downstream and the upstream river channel-bed monitor cables. Note the galvanized steel pipe that is parallel to the existing conduit for the pressure transducer on the downstream column.

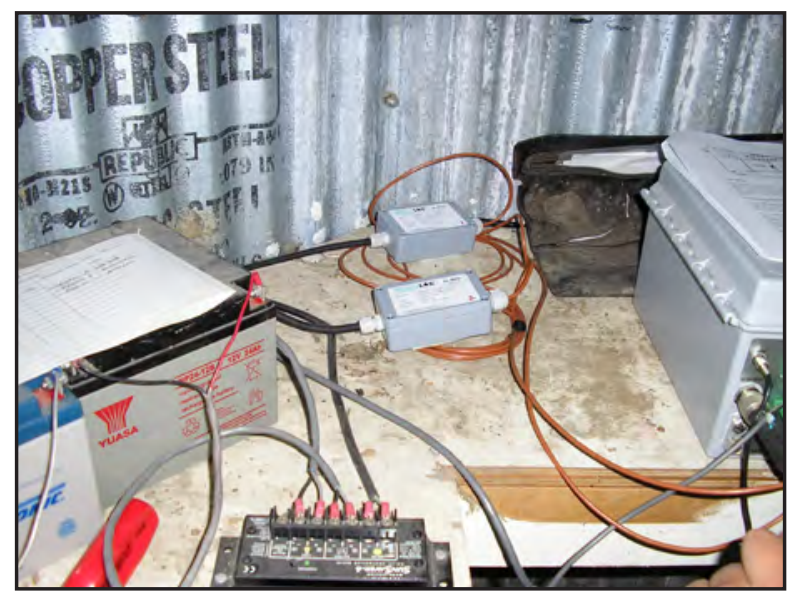

Wiring of NEMA 0183 to SDI-12 conversion devices necessary to ensure recording and transmission of river channel-bed monitor depth soundings.

Figure 6. Installation of river channel-bed monitors on structure L-534 over the Chariton River at Novinger, Missouri. 

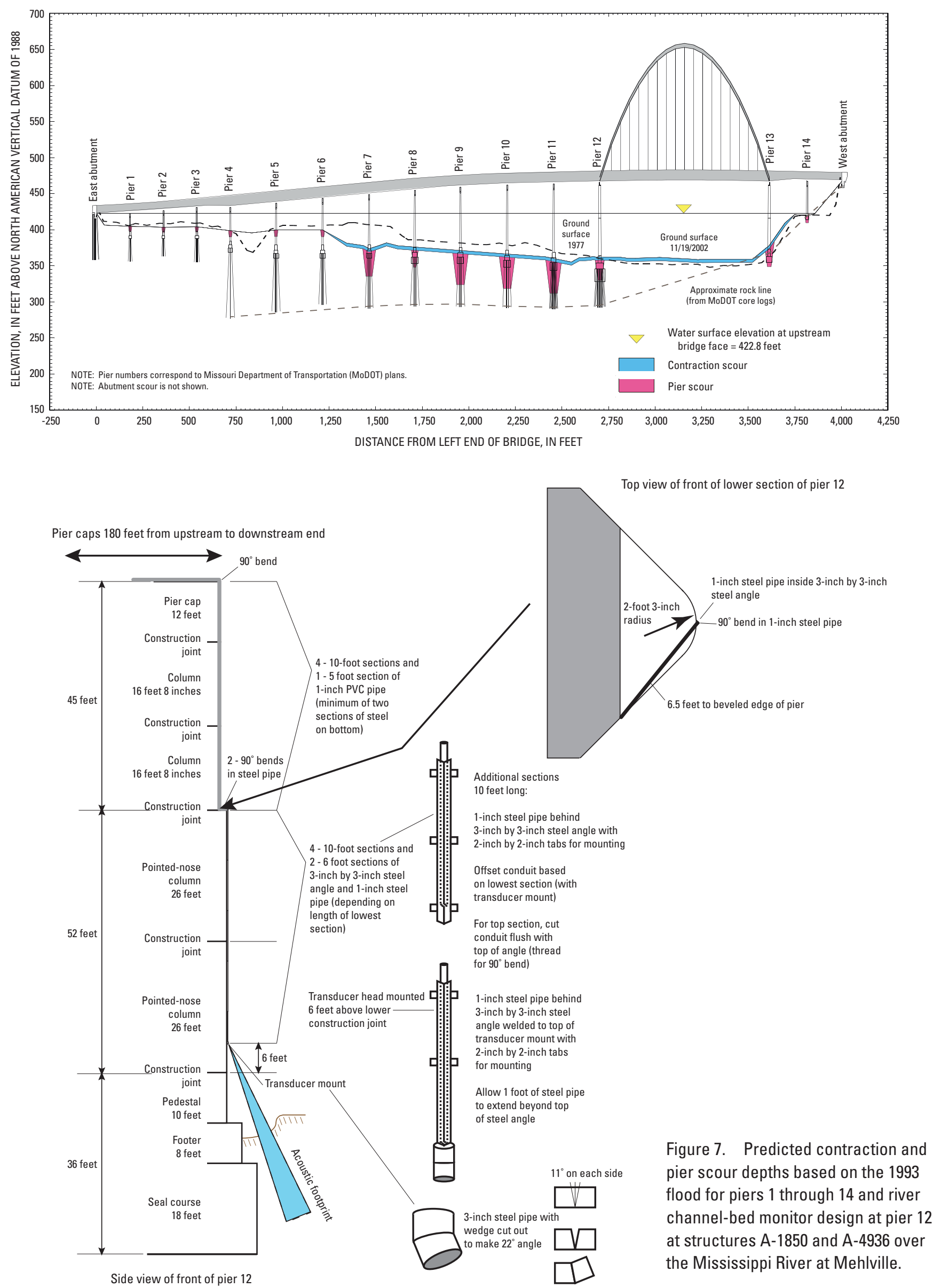
shielded cable along the remainder of the pier nose, along the pier cap, and into the shelter.

Installation of RCBM's at the JBB required a crane and suspended basket in which to work from the water surface up to the cap along the upstream and downstream nose of pier 12 (fig. 8). Expandable anchor bolts were used to mount the steel pipe and angle along the pier nose through pre-drilled holes in the 2- by 2-inch tabs located at increments along the 10-foot sections (figs. 7 and 8). In contrast to the Chariton River sites, this location did not have a pre-existing continuous stage recording device. This required the installation of a water stage sensor and DCP to provide corresponding hydrographic record. A non-contact water surface sensor was clamped to the substructure girders of the bridge and the attached shielded cable consisting of power, data, and ground wires was run to the shelter housing the DCP (fig. 8).

\section{River Channel-Bed Monitor Results}

All monitoring locations were established to provide channel-bed data near bridge piers. General channel-bed behavior, such as scour and deposition, are somewhat altered because of the effect of a bridge pier as a flow impediment. Typically, the scouring condition of the channel bed is exacerbated from a horseshoe vortex caused by increased velocities near the base of the pier at the upstream nose that contributes to the removal of bed material (Richardson and Davis, 2001). Data received from RCBM's outside the vicinity of impediments likely would illustrate a better correlation of scour and deposition to the rising and falling limb of a hydrograph rather than monitoring channel-bed change downstream or upstream from a pier during a hydrologic event.

In addition to the effects of an impediment, channelbed changes inconsistent with theoretical expectations of scouring and deposition based on the hydrographic record might indicate the presence of bedforms, which are structures resulting from the movement of bed material due to flow. In sand channel beds, the sequence of bedform development can be correlated to an increase in velocity (Leopold and others, 1964). In most sand-bed channels, ripples or dunes exist as a result of velocities present during median or base flows; however, as velocities begin to increase, dunes tend to dissipate to a point where flow begins to approach a state where forces, including gravity and viscosity, are overcome by the increasing movement of water. At this point (known as critical flow), antidunes begin to form in relation to surface waves and these antidunes progressively move upstream, continually forming, dissipating, and reforming (Leopold and others, 1964). In general, erosion of ripples and dunes occurs as a result of a lack of resistance of bed material with increasing fluid stress. However, the amount eroded cannot be conveyed as bed load without an increase in applied stress; therefore, bed material is re-deposited, initially representing an unstable channel condition (Leopold and others, 1964). A re-deposition of bed material is done in such a way that new resistance is created, ultimately returning a steady state to the channel. These dynamics describe the foundation for development and migration of bedforms (Leopold and others, 1964).

Movement in the channel-bed record during inter-event flows indicated the existence of these bedforms. Other anomalies observed in the channel-bed record may indicate debris accumulation. Although the timing for scouring and deposition was not always expected based on the shape of the hydrograph, overall results for most monitoring locations indicated direct responses to hydrologic events.

RCBM's identified some noise and backscatter, primarily as a result of sediment transport and periodic events of submerged debris movement. In addition, substantial noise was evident during periods where sounding depths were approximately 1.5 feet or less. At shallow depths, the 235 kilohertz frequency transmitting from the RCBM caused "vibration" or "ringing" as the transducer head "pinged" the channel bottom at close distances. During these periods (specifically for structure L-344), a false second return, or echo, which was offset in the channel bottom record, was evident with accompanying noise. Depth soundings that occurred every 15 minutes resulted in a large data set. The amount of data allowed the observation of well-defined trends through periodic noise and ultimately justified a smoothing of the record without compromising the true representation of the channel bed. To further ensure accurate channel-bed record during excessive noise or offset channel-bed signatures resulting from shallow depths, physical depth measurements periodically were made to the channel bed and translated to datum. RCBM data were always within 0.4 foot of the physical measurement (table 1).

\section{Chariton River near Prairie Hill (Structure L-344)}

On August 20, 2007, an RCBM was installed behind the upstream conical column of pier 4 as a pilot study. Within a few days, a 12-foot rise in stage triggered approximately 3 to 4 feet of scour (fig. 9). The scoured bed condition was sustained for nearly 17 days (fig. 9) until the presence of a bedform began to fill the hole during the middle of September 2007. Although the majority of the channel-bed record reflected some sort of direct hydrologic response at this location, the presence of bedforms as well as the flow impediment on which the RCBM was installed (pier 4) had contradictory or additive effects on expected scour and depositional behavior. A potential migrating bedform appeared before substantial scouring that occurred July 24, 2008, as a result of increasing velocities associated with the rising limb of the peak. The presence of this bedform may have produced an additive effect whereby scour was increased at the peak as the dune trough crossed the scour hole. Conversely, a filling effect can arise from cases where the crest of the bedform is passing through the scour hole (Pittaluga and others, 2004). For example, the rising limb of a prior peak on June 24, 2008, possessed nearly the same magnitude and duration as compared to the July 24, 2008, 

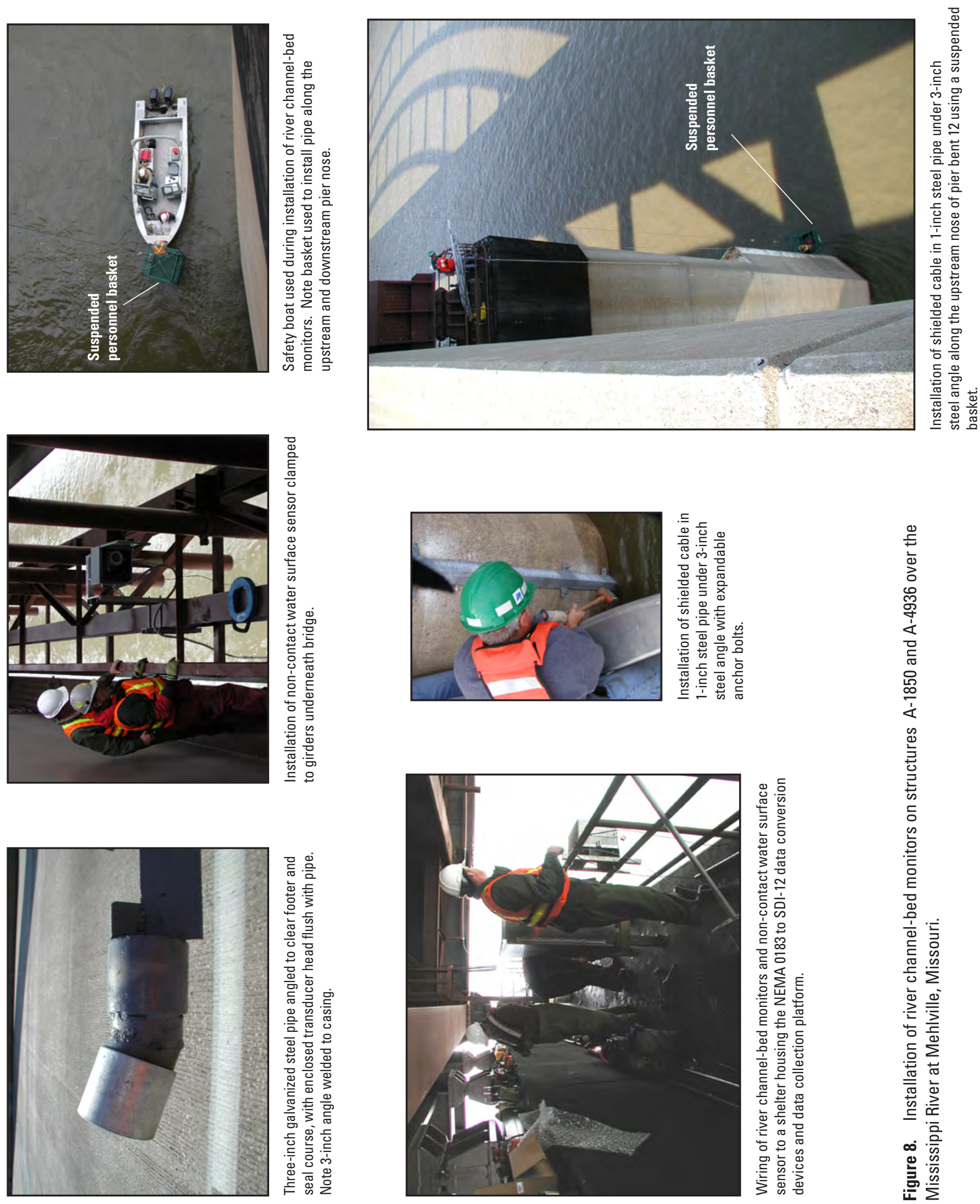
Table 1. Depth soundings near locations of river channel-bed monitors on the downstream side of the indicated column of bridges on the Chariton River in Missouri

[ft, feet; RCBM, river channel-bed monitor; NGVD 29, National Geodetic Vertical Datum of 1929; --, no measurement]

\begin{tabular}{|c|c|c|c|c|c|c|c|}
\hline \multirow[b]{2}{*}{ Date } & \multicolumn{2}{|c|}{$\begin{array}{c}\text { Upstream column of pier } 4 \\
\text { of structure L-344 }\end{array}$} & \multirow[b]{2}{*}{ Date } & \multicolumn{2}{|c|}{$\begin{array}{c}\text { Upstream column of pier } 7 \\
\text { of structure L-534 }\end{array}$} & \multicolumn{2}{|c|}{$\begin{array}{c}\text { Downstream column of pier } 7 \\
\text { of structure L-534 }\end{array}$} \\
\hline & $\begin{array}{c}\text { Measured } \\
\text { bed elevation } \\
\text { (NGVD 29) } \\
\text { (ft) }\end{array}$ & $\begin{array}{l}\text { RCBM bed } \\
\text { elevation } \\
\text { (NGVD 29) } \\
\text { (ft) }\end{array}$ & & $\begin{array}{c}\text { Measured } \\
\text { bed elevation } \\
\text { (NGVD 29) } \\
\text { (ft) }\end{array}$ & $\begin{array}{l}\text { RCBM bed } \\
\text { elevation } \\
\text { (NGVD 29) } \\
\text { (ft) }\end{array}$ & $\begin{array}{c}\text { Measured } \\
\text { bed elevation } \\
\text { (NGVD 29) } \\
\text { (ft) }\end{array}$ & $\begin{array}{l}\text { RCBM bed } \\
\text { elevation } \\
\text { (NGVD 29) } \\
\text { (ft) }\end{array}$ \\
\hline 21-Aug-07 & 631.2 & 631.1 & 22-May-08 & 733.3 & 733.1 & 731.8 & 731.6 \\
\hline 18-Sep-07 & 631.7 & 631.8 & 2-Jul-08 & -- & -- & 728.8 & 728.6 \\
\hline 6-Mar-08 & 627.7 & 627.4 & 7-Jan-09 & -- & -- & 729 & 729.3 \\
\hline 28-Sep-08 & 632.6 & 632.5 & 8-Jul-09 & 730.3 & 729.9 & 730.6 & 730.9 \\
\hline 21-Jul-09 & 630.8 & 630.5 & & & & & \\
\hline
\end{tabular}

peak event, yet showed a minimal scouring response possibly as a result of the presence of bedforms.

From August 21, 2007, through February 21, 2008, channel-bed records depict channel-bed elevation changes as large as 4 feet and the presence of bedforms evident during inter-event flows in September, November, and the beginning of December (fig. 9). From February 21 through August 21, 2008, channel-bed changes were as large as 13 feet, and indications of substantial bedforms occurred during the middle of May and toward the end of July during inter-event flows (fig. 9). The maximum channel-bed change of 13 feet was attributable to a record peak flood event at this location of 38,400 cubic feet per second that occurred on July 27 , 2008. This was the largest recorded peak flood in 78 years of record and was statistically defined within a 0.2 to 1 percent annual exceedence probability or between a 500- and 100-year recurrence (Robert Holmes, U.S. Geological Survey, written commun., 2009). From August 21, 2008, through February 21,2009 , bed changes as large as 10 feet and the presence of bedforms during inter-event flows in November were noted (fig. 9). Finally, from February 21 through August 21, 2009, channel-bed changes were as large as 5 feet, but bedforms could not be distinguished during this period (fig. 9). As previously stated, the channel bed responded to hydrologic events, including an event beginning August 17, 2009, that depicted scouring on the rising limb, which continued through the end of the data collection period on August 21, 2009.

Channel-bed data collection at this location was compromised from August 15 to September 12, 2008, as a result of deposition of sediments close to the transducer head of the RCBM (fig. 9). The occurrence of this deposition produced an indistinguishable channel-bed signature as a result of noise and secondary echoes. In addition, no valid data were collected during middle and late January 2009 because of ice accumulation (fig. 9). Another period of missing channel-bed and stage record occurred March 14 through March 16, 2009, as a result of equipment power failure.

\section{Chariton River at Novinger (Structure L-534)}

On May 22, 2008, RCBMs were installed on the downstream side of the upstream and downstream columns of pier 7. After the installation, the channel-bed record appeared to be depicting bed changes for the upstream column (fig. 10), but progressively became steady and flat, indicating exposure of the footer behind the upstream column. After the installation of the RCBM at the downstream column, the RCBM was sounding the footing. The transducer head was moved beyond the footer an additional foot (extended from 2 to 3 feet) at both upstream and downstream columns to ensure adequate sounding of the channel bed (fig. 10).

The downstream channel-bed record depicted an elevation of 731.5 feet, which was within 0.2 foot from the elevation of the top of the footer of 731.7 feet, as indicated from MoDOT bridge plans. As bed monitoring continued at the downstream column from May 22 through November 22, 2008, depositional responses to hydrologic events occurred near the end of June, end of July, and middle of September. A period of record peak flood event of 30,200 cubic feet per second occurred July 25, 2008, and was the largest recorded flood in 83 years of record, with a statistically defined annual exceedence probability between 2 to 4 percent, or in the range of a 50- to 25-year recurrence (Robert Holmes, U.S. Geological Survey, written commun., 2009). The RCBM at the upstream column revealed an exposed footing, but the channel-bed record at the downstream column did not indicate any substantial response to the magnitude of this peak (fig. 10). Channel-bed monitoring at the downstream column indicated channel-bed changes as large as 3 feet and difficulty in ascertaining the presence of bedforms from May 22 through November 22,2008 . For the same period of time, the footer at the upstream column was progressively more exposed, which was made apparent by a steady and flat channel-bed signature during July through October. Channel-bed fluctuations at the upstream column were as much as 1.5 feet before the footer was exposed and after the transducer was moved during this period. 


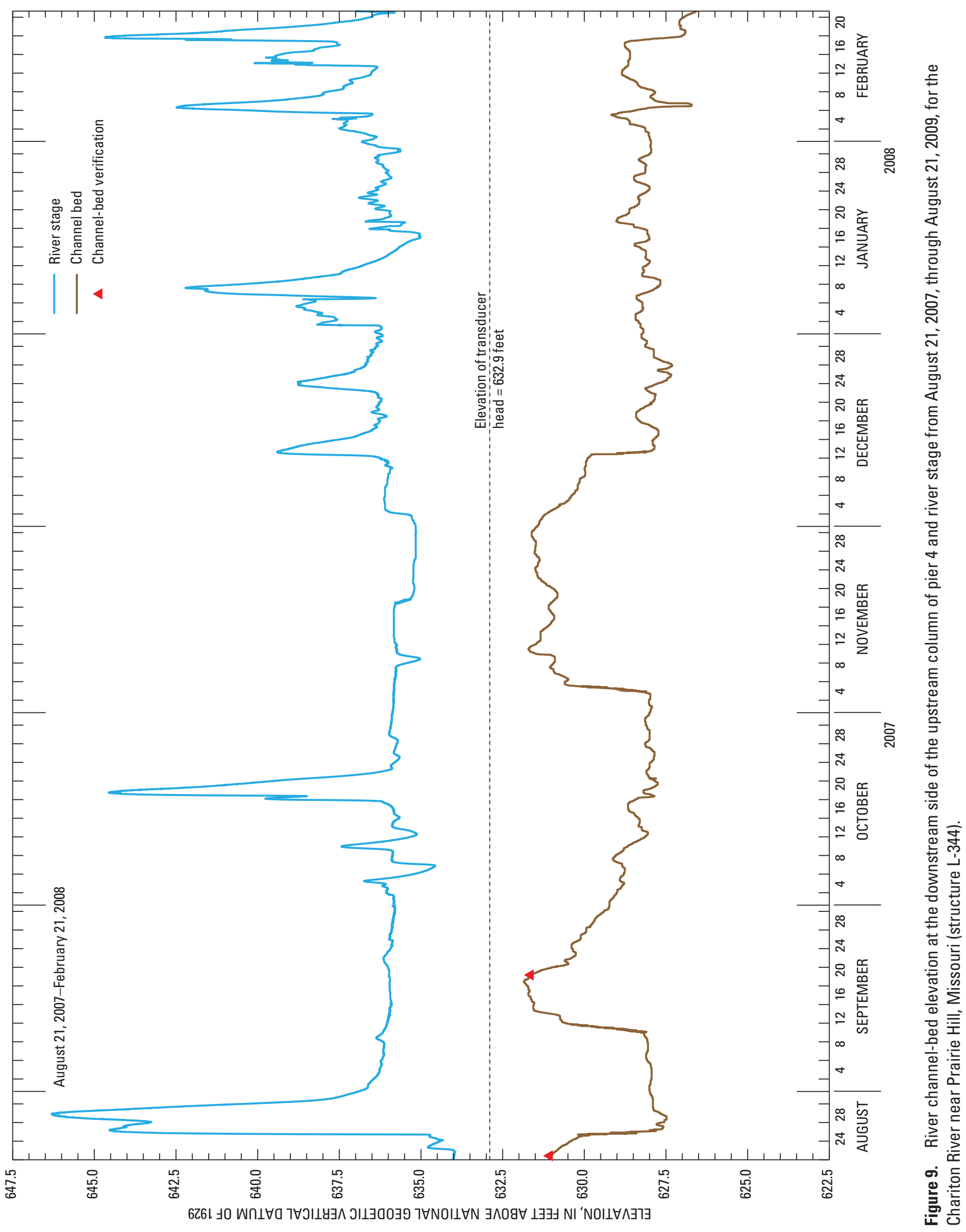




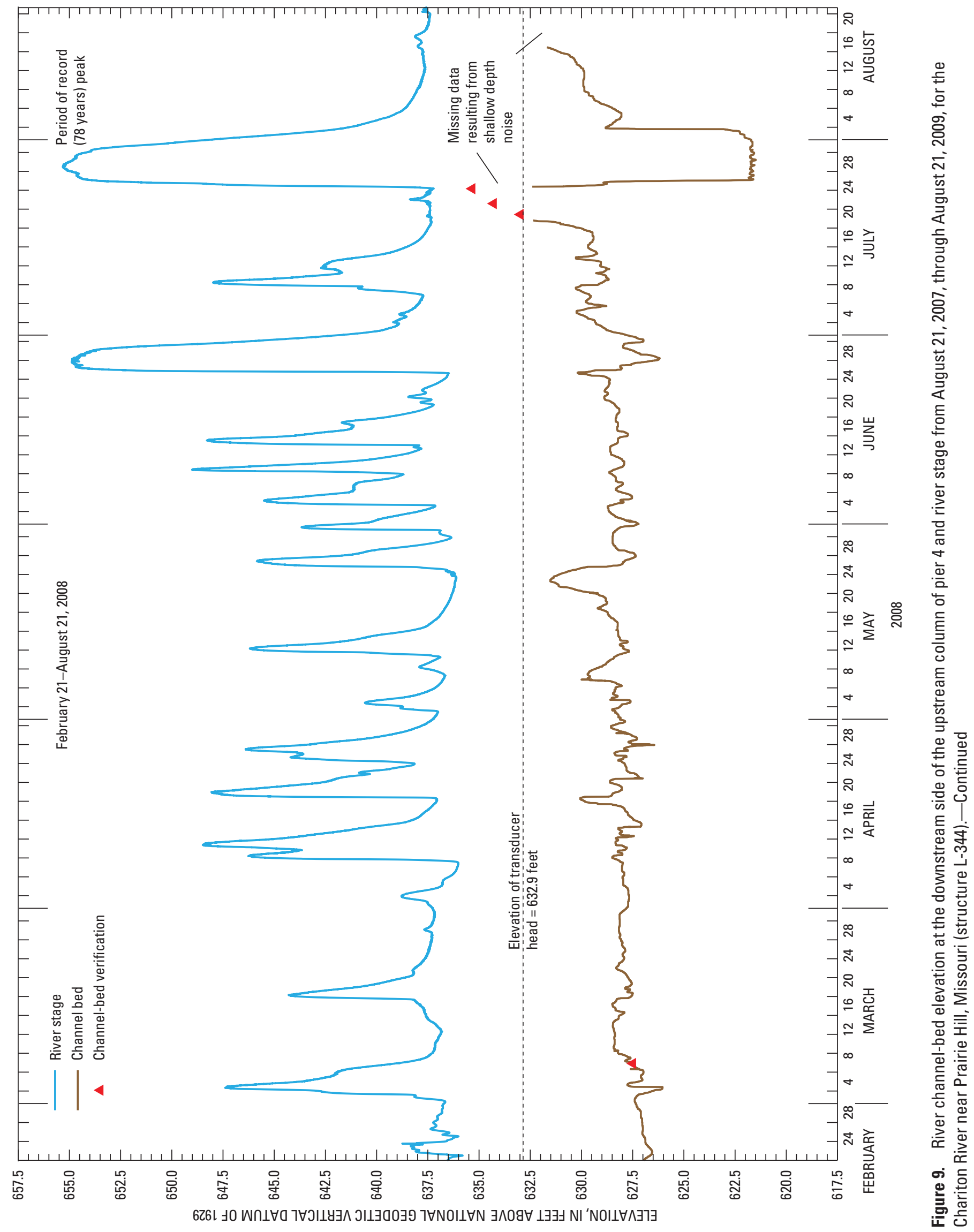




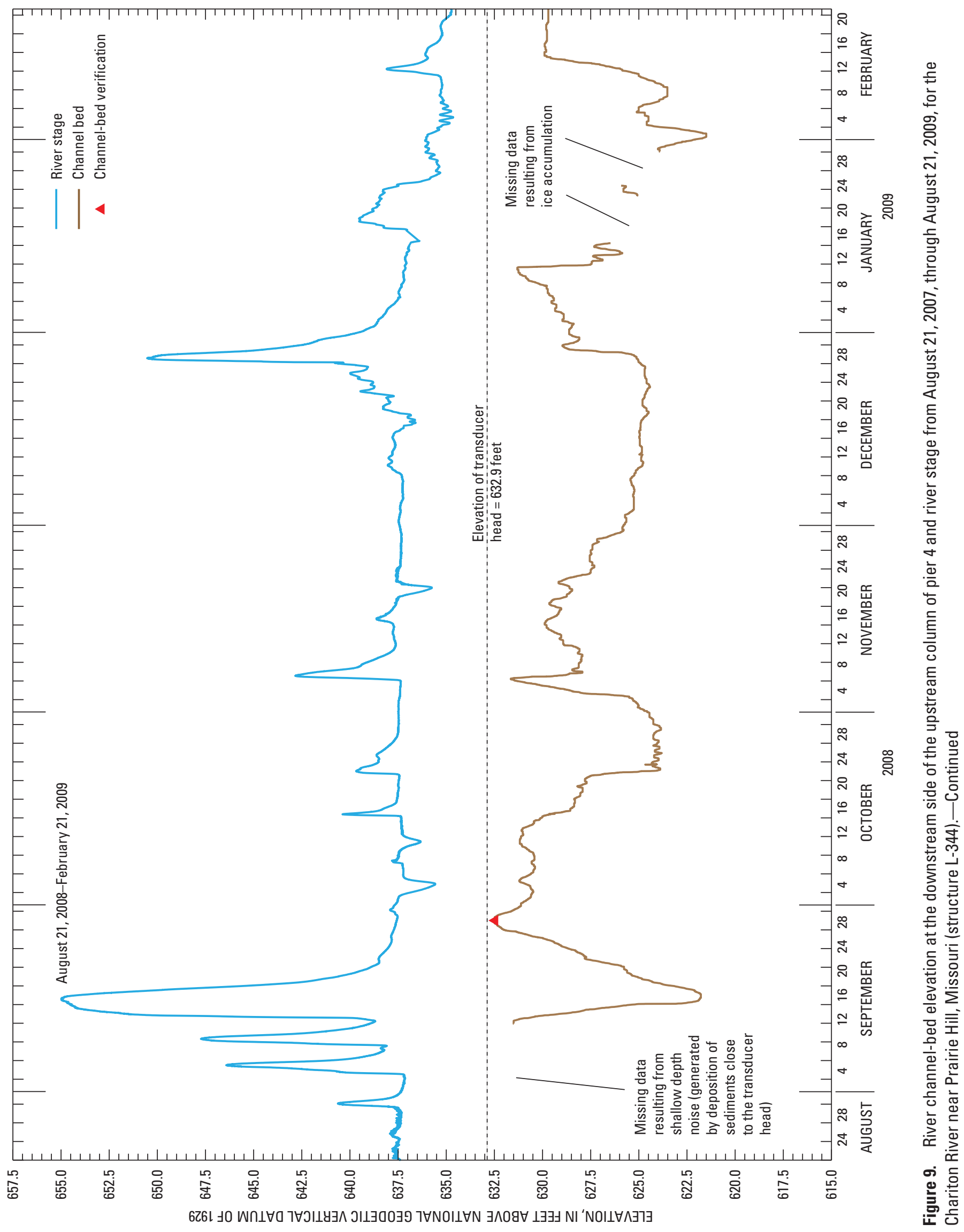




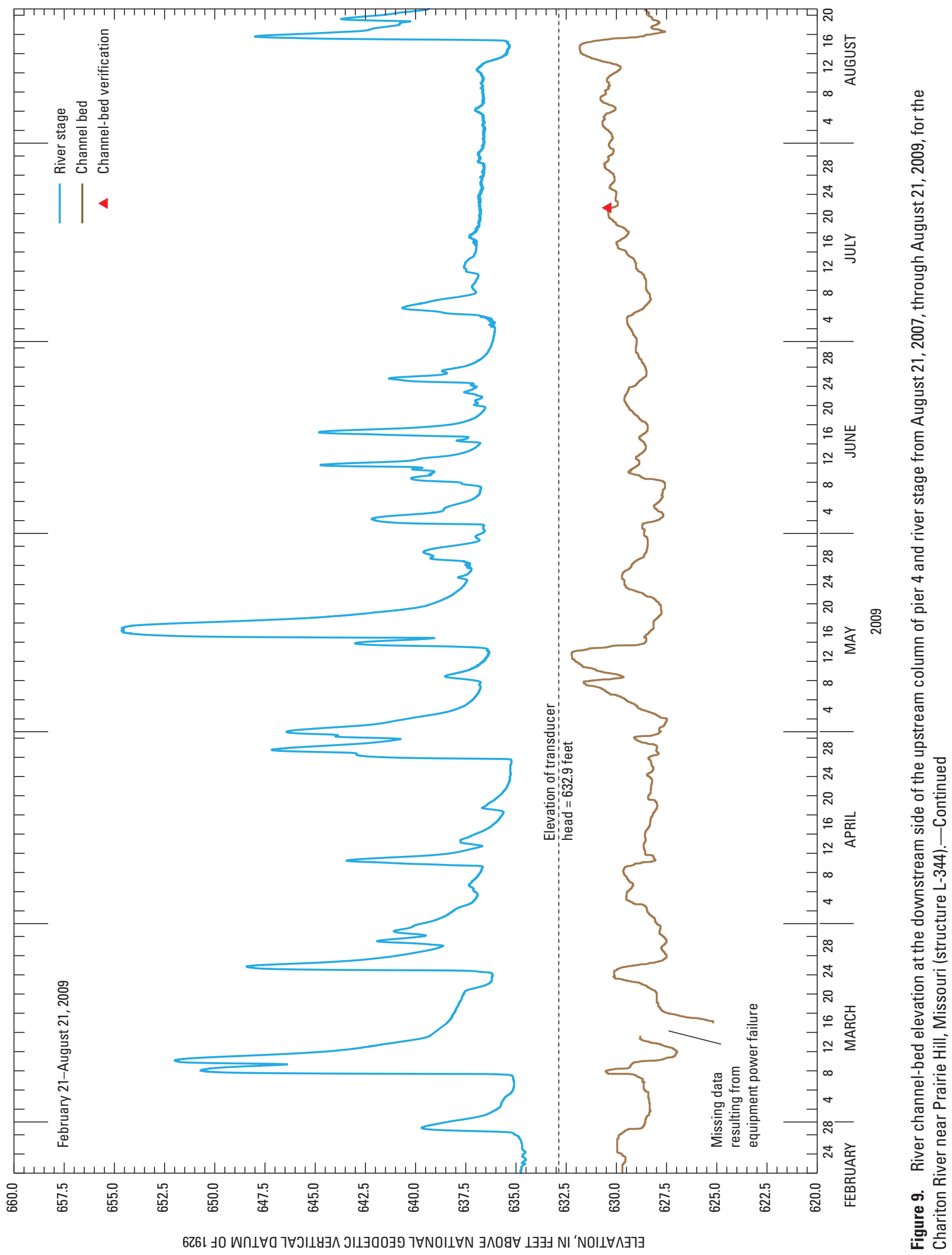


During November 22, 2008, through May 22, 2009 (fig. 10), RCBM data at both upstream and downstream columns were examined for correlation with hydrologic events. Channel-bed scouring at both upstream and downstream columns appeared to be a response to increasing velocities associated with rising limbs of hydrologic events occurring December 22, 2008, March 8, March 24, April 27, and May 16, 2009 (fig. 10). A subtle time lag appears to be evident between event-related scouring from the upstream to downstream monitoring locations. Overall, channel-bed elevation changes were as much as 5 feet at the upstream column and 3 feet at the downstream column. Although bedforms may be "concealed" as they contribute to the scour and deposition processes observed, a distinguishable bedform is evident at the upstream column during inter-event flows in late January and through the month of February. During the latter part of February to the beginning of March, the transition (occurring February 26) of a bedform, as depicted from the upstream monitoring location to the downstream monitoring location, may be apparent (fig. 10).

During May 22 through August 22, 2009, channel-bed changes as large as 6 feet occurred at the upstream column, and changes as large as 3 feet occurred at the downstream column (fig. 10). An inter-event flow period occurred July 12 through August 12, 2009, for which there was no channelbed change or potential bedform movement. Hydrologic events occurring earlier in this data collection period (May 22 through August 22, 2009) demonstrated channel-bed responses that were atypical compared to scour and depositional responses observed from November 22, 2008, through May 22, 2009 (fig. 10).

\section{Mississippi River at Mehlville (Structures A-1850 and A-4936)}

Completion of the installation of RCBM's at the upstream and downstream nose of pier 12 occurred on October 24, 2008. Overall data collection at this location indicated minimal channel-bed elevation changes, without response to flow events depicted in the hydrographic record. At the downstream nose, bed-elevation changes were less than 0.7 foot from October 24, 2008, through April 24, 2009 (fig. 11). Similar to the downstream nose, the channel-bed elevation never changed more than 1.5 feet at the upstream nose of pier 12 during 68 days of data collection from October 24 through December 31, 2008 (fig. 12). From December 22 through December 31, 2008, suspected ice accumulation began to interfere with the RCBM, resulting in false channel-bed signatures and eventual damage to the transducer head (fig. 12). Floating ice sheets were documented within the vicinity of the JBB during the latter part of December 2008 throughout the middle of January 2009. A site visit was made February 6, 2009, to inspect the RCBM above the water surface. Some damage had occurred to the steel angle protecting the 1-inch pipe that housed the shielded cable. To inspect and service the RCBM, the river stage must be below 370 feet (NAVD 88), which was not reached throughout the remainder of data collection.

The downstream monitoring location documented channel-bed changes as large as 5 feet over the 182-day period of data collection. Monitoring from April 24 through August 24,2009 , continued to reveal subtle changes in bed elevation at the downstream nose (fig. 11). Grounding issues with equipment during electrical storms caused missing data for several complete and partial days during this data-collection period.

Bathymetric surveys were conducted on October 2, May 13, and July 8, 2009, using a multibeam sonar unit that provided high-resolution bathymetry depicting a detailed three-dimensional representation of the Mississippi River channel bed around the JBB. The multibeam sonar unit uses acoustic energy and records reflected echo from a series of pulses that are distributed in a swath across the riverbed (National Oceanic and Atmospheric Administration, 2009). Sound pulse generators and receivers used in this application created a swath that was 130 degrees wide perpendicular to, and 0.5 degrees wide parallel to, a survey line, and contained 512 individual points representing depth across the swath (Richard Huizinga, U.S. Geological Survey, written commun., 2009). A bathymetric survey conducted on October 2, 2008 , did not indicate any change in channel-bed elevation or presence of distinguishable bedforms; however, subsequent surveys conducted May 13 and July 8, 2009, revealed the presence of a bedform upstream from pier 12 (from the May 13,2009 , survey) and the migration and presence of additional bedforms upstream and downstream from pier 12 (from the July 8, 2009, survey) (fig. 13). The presence of bedforms from the bathymetric survey can be correlated to notable bedform movement (fig. 11) occurring June 7 through June 14, June 27 through June 30, and August 6 through August 23, 2009.

\section{River Channel-Bed Monitor Uncertainty and Limitations}

The Smart ${ }^{\mathrm{TM}}$ sensor transducer used in these applications has a depth range limitation from 0.5 meter to 100 meters ( 1.6 feet to 328.1 feet) and an accuracy of $+/-20$ centimeters ( 7.9 inches) up to a depth of 5 meters (16.4 feet) and 3 percent of the depth from 5 meters to 100 meters (16.4 feet to 328.1 feet) (Irene Robb, Airmar Technology Corporation, oral commun., 2009). The sensors assume a fixed speed of sound in water (1,500 meters per second; 4,921.3 feet per second); that in reality changes due to temperature and pressure (Irene Robb, Airmar Technology Corporation, oral commun., 2009; John Bauchat, Airmar Technology Corporation, written commun., 2009). Physical measurements using a leveling rod at both Chariton River locations never varied more than 0.4 foot from the RCBM measurement (table 1). Readings from the rod were subtracted from the water surface elevation datum (NGVD 29) to obtain a channel-bed elevation that was compared to the current reading from the RCBM. The leveling 


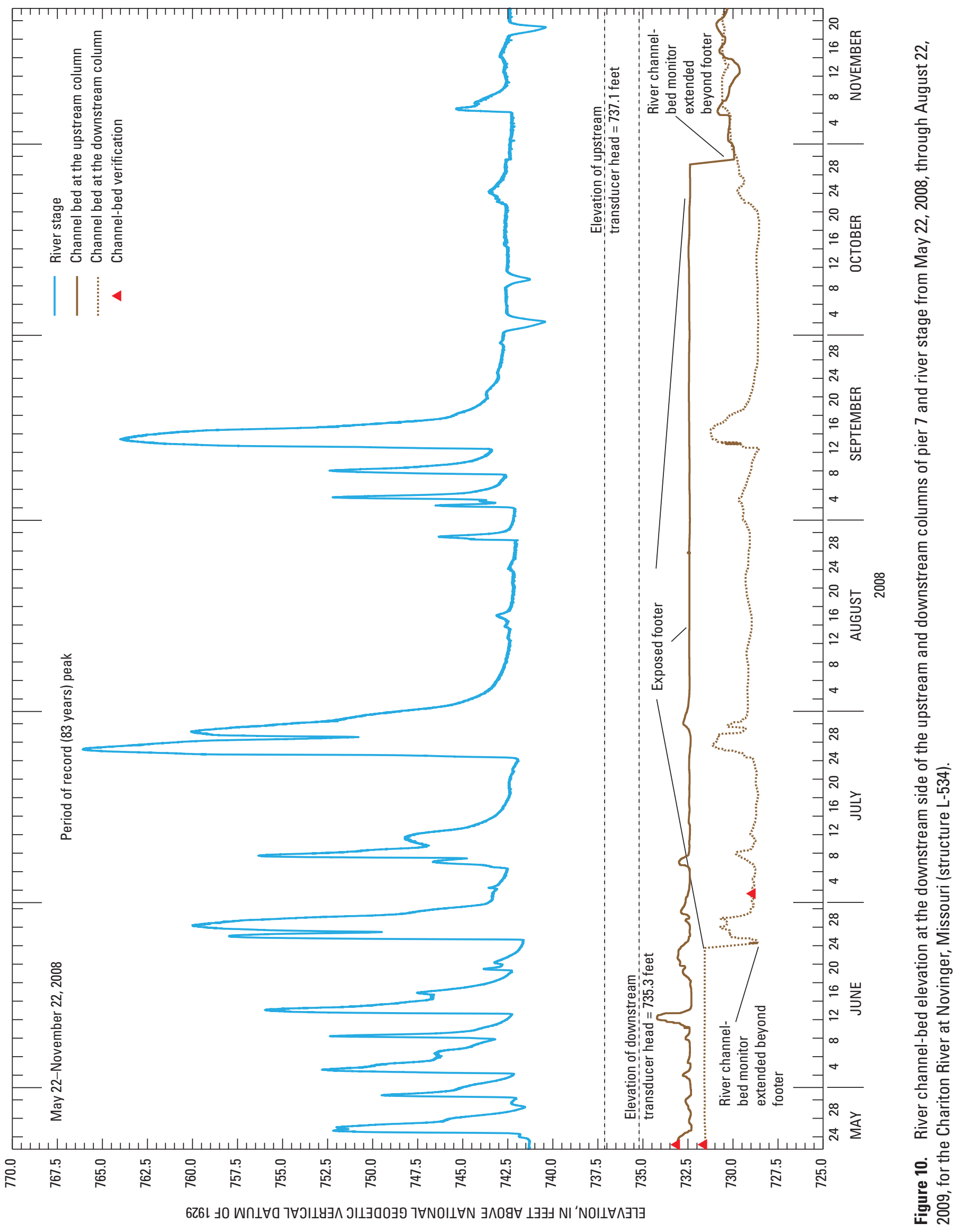




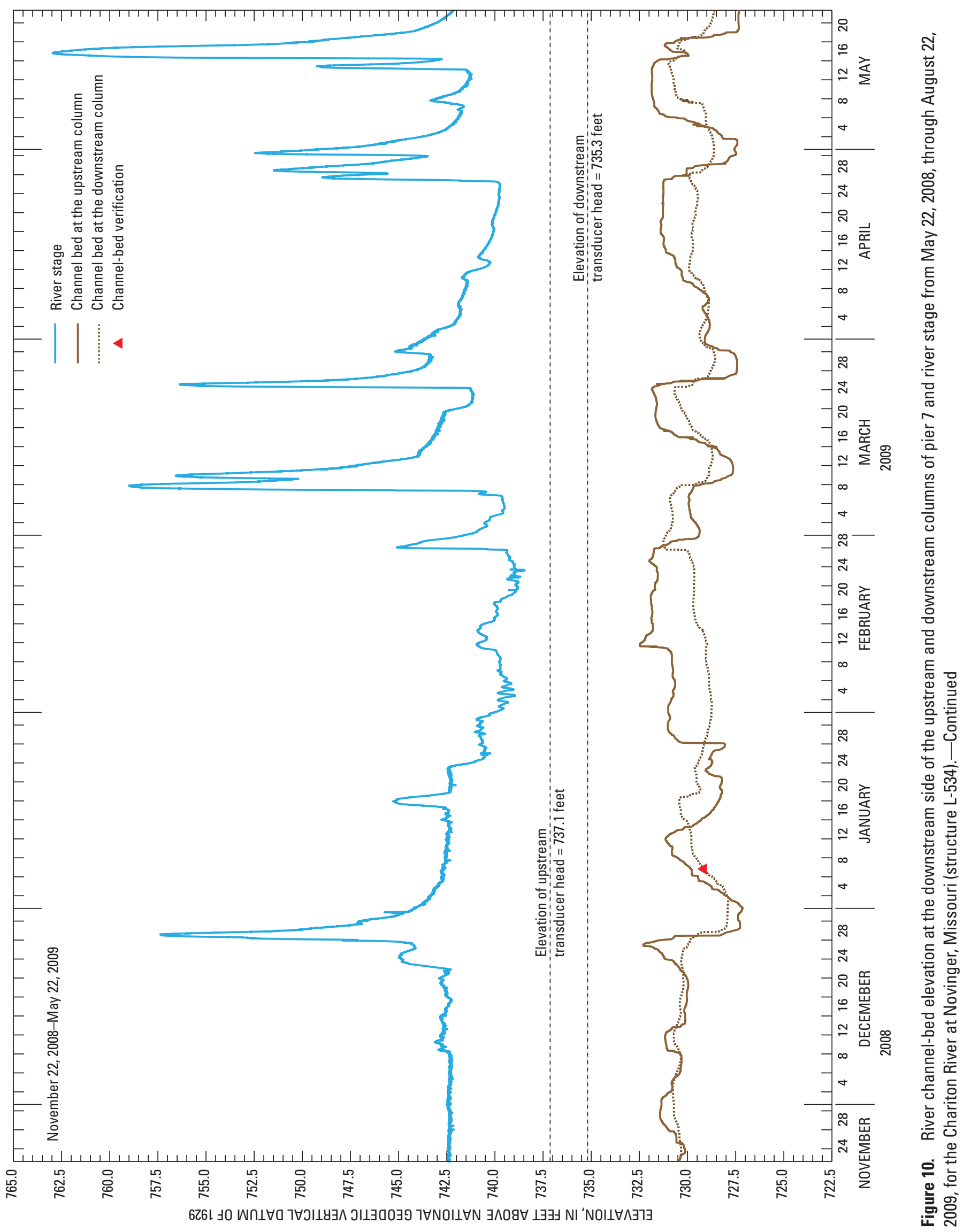




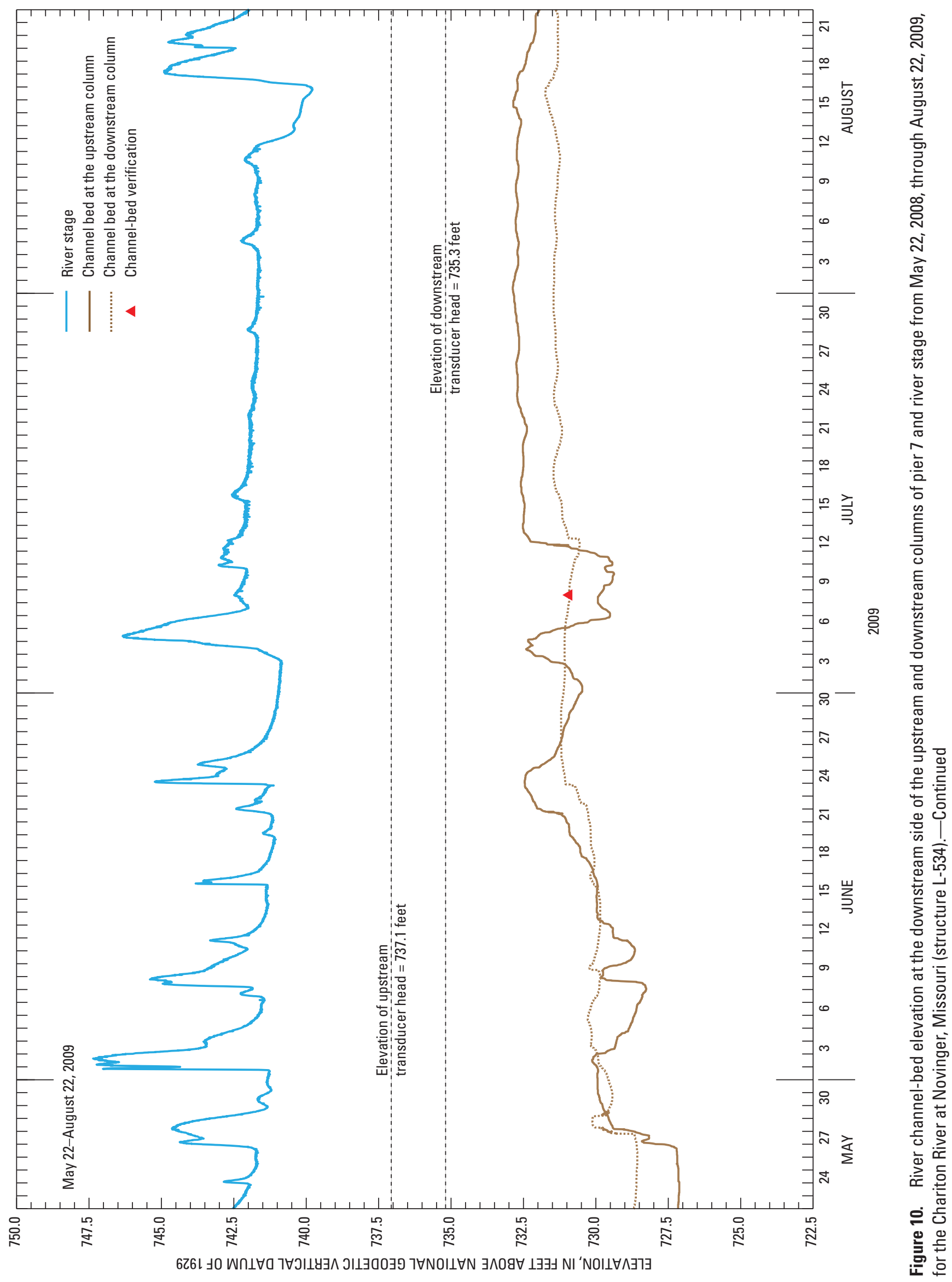




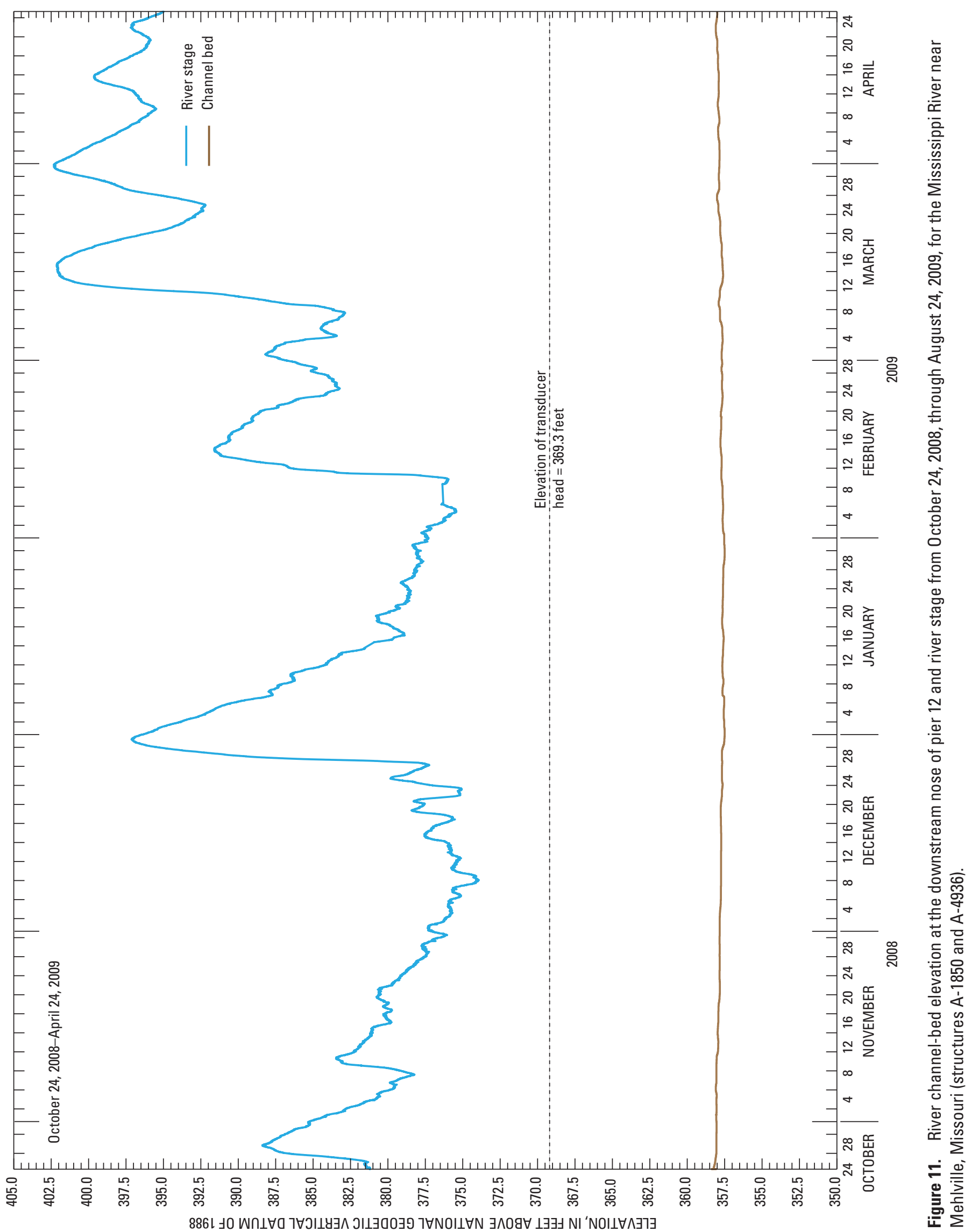




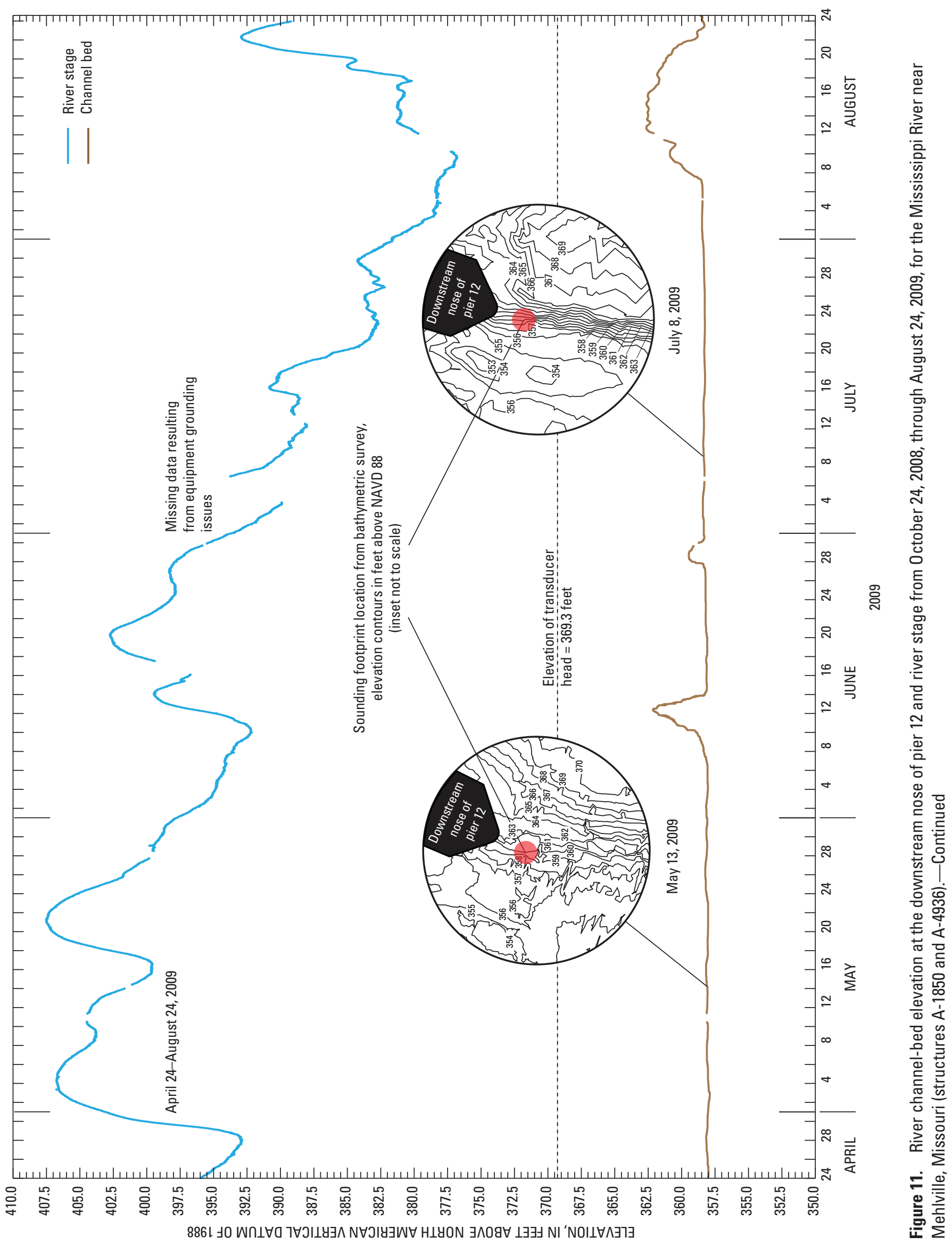




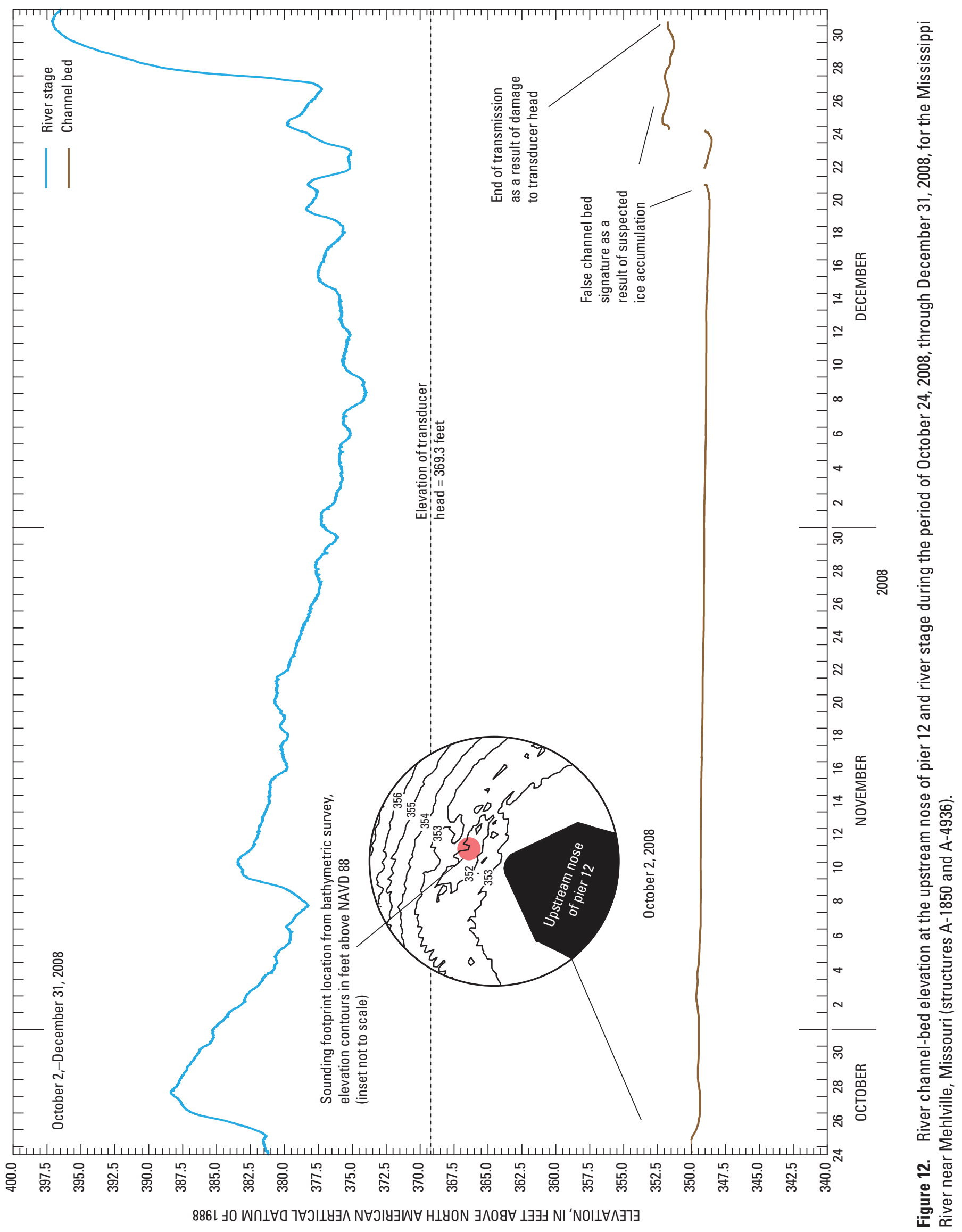



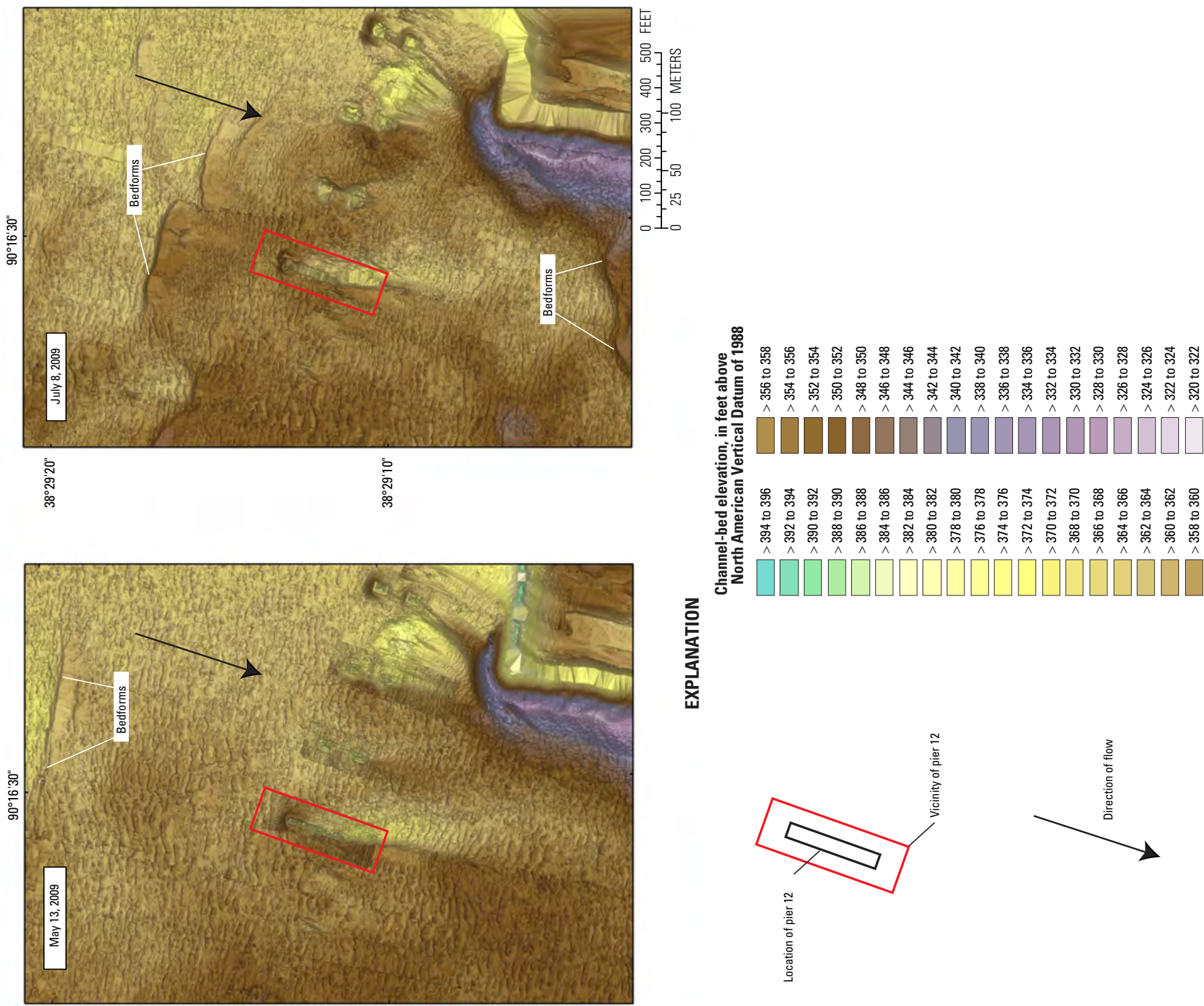

진
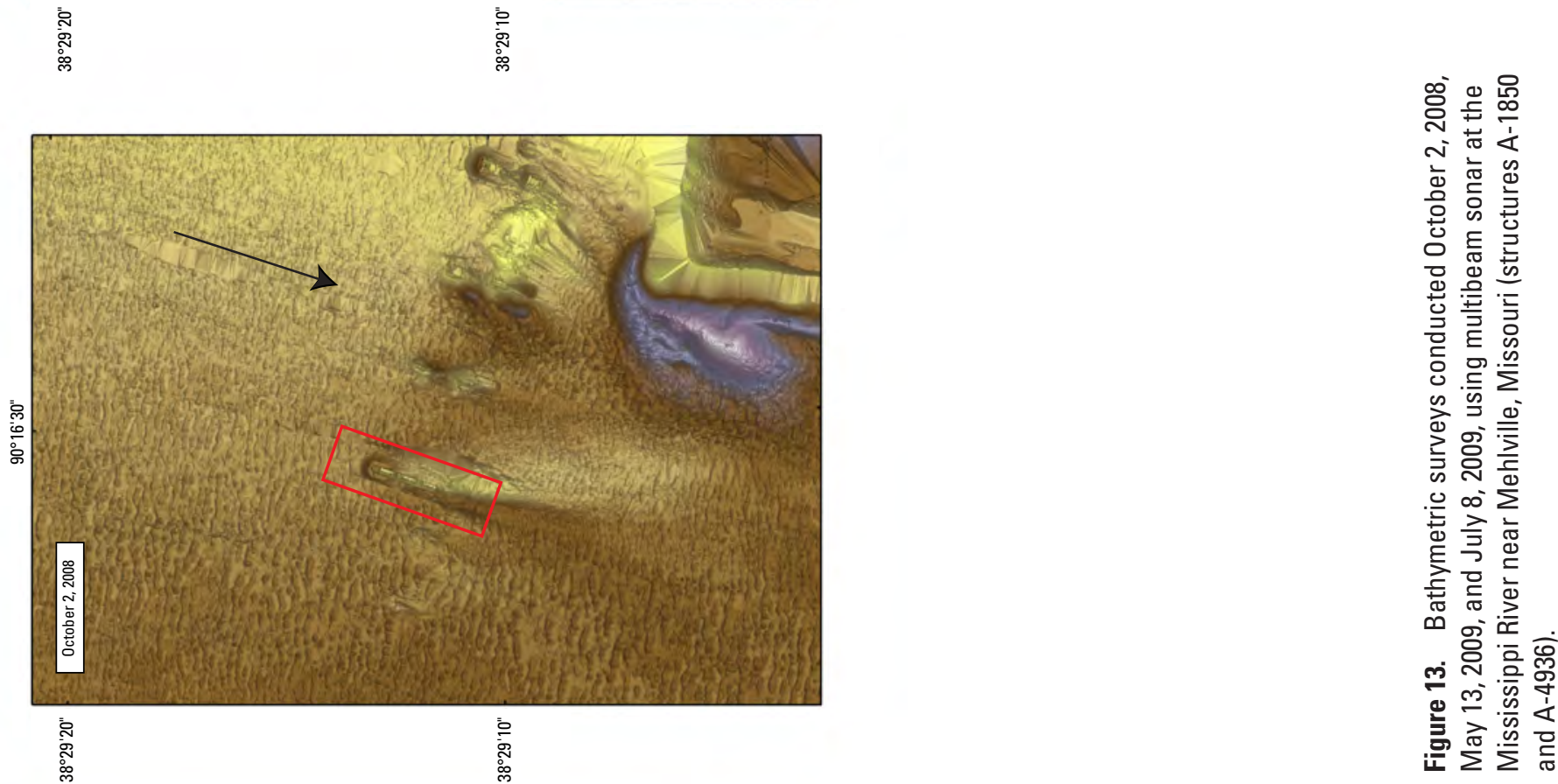
rod was positioned at the side of the transducer, as opposed to obtaining a depth directly underneath the head, which may have contributed a small amount of additional error. Referring to the specifications mentioned earlier and physical measurements made during the period of data collection for both Chariton River sites, the monitored channel bottom was typically within 0.5 foot of the physical measurement and never varied more than 1 foot of the true value during substantial hydrologic events. For the Mississippi River location, coincident bathymetric surveys were compared with the channel-bed measurement from the RCBM. Referring to figure 11, bathymetric surveys occurring May 13 and July 8, 2009, depicted channel-bed elevations at the downstream nose that correlated well (within 0.5 foot) with RCBM measurements. Data from a prior bathymetric survey on October 2, 2008 appeared reasonable at the upstream nose considering the channel-bed record of the RCBM did not begin until October 24, 2008 (fig. 12). However, assuming a flat channel bottom at the upstream and downstream nose, channel-bed record from RCBMs at the Mississippi River location have approximately 7 percent error due to the angle in which the transducer head was mounted and the signal interface with the channel bottom. Depth measurements did not take into account the angle of the installation; therefore, relative distortions of bedforms or scour holes could be biased high as much as 7 percent.

Challenges in adopting use of single-beam sonar technology are primarily location and environmental factors. The location of the RCBM needs to be in a pool with sufficient depth at a base-flow condition so that during hydrologic events, the deposition of sediment does not accumulate too close to the transducer head and cause excessive noise and additional echo returns as discussed in the river channel-bed monitor results section. For periods when channel-bed data are indicating noise from shallow monitoring, more frequent field inspections are needed to help smooth and estimate data during periods of excessive noise. Environmental factors, such as ice accumulation and floating debris, are potential concerns that may cause periods of missing record. A proper design can mitigate damage as well as accumulation from floating ice and debris; however, the reliability of the RCBM can be affected during occasions where ice and debris collect at depths below the transducer head.

Overall, the Chariton River installations had minor limitations in providing continuous channel-bed record. The Chariton River near Prairie Hill (structure L-344) had 39 days of missing record out of 730 days, or about 5 percent. Although footing exposure was evident for both monitors at the Chariton River at Novinger (structure L-534), neither monitor had any missing record over the period of 457 days.

The Mississippi River near Mehlville (structures A-1850 and A-4936) location presented challenges during the installation of RCBMs; specifically, ensuring adequate depths of the transducer head and sufficient clearance of the acoustic signal over the footer and seal course to the channel bottom. The frequency and magnitude of ice accumulation on the Mississippi River during the latter part of December 2008 into the middle of January 2009 affected the RCBM at the upstream nose. A voltmeter, used to conduct a continuity check in the shielded cable through the transducer head, indicated a closed circuit. In addition, diagnostics of the DCP and wiring did not provide any more evidence of why no data were being received. Although a field inspection indicated no damage near the water surface, the transducer head needed to be examined and was not serviceable because of high river stage throughout the data collection period. Unlike the monitor at the upstream nose which reported only 68 days (37 percent of the data collection period), channel-bed record on the downstream nose was continuous throughout the 182-day data collection period.

\section{Summary and Conclusions}

A single-beam sonar technology, used primarily for marine applications, was adopted as a river channel-bed monitor (RCBM) to evaluate channel-bed behavior in response to hydrologic conditions at two locations crossing the Chariton River and one location crossing the Mississippi River. The RCBM used for this data collection effort utilized Smart ${ }^{\mathrm{TM}}$ sensor technology, a technology composed of active electronics in the transducer head allowing function of the transducer element as well as signal processing. The RCBM was integrated with an existing streamgage data collection platform that collected readings every 15 minutes and transmitted hourly. As a result of historically documented channel-bed changes, an initial location crossing the Chariton River near Prairie Hill (structure L-344) was chosen as a pilot study for nearly a year until additional sites crossing the Chariton River at Novinger (structure L-534) and the Mississippi River near Mehlville (structures A-1850 and A-4936) were monitored by the U.S. Geological Survey in cooperation with the Missouri Department of Transportation. Bed elevation data for the Chariton River at Novinger and the Mississippi River near Mehlville were provided to the World Wide Web for real-time monitoring.

With the exception of ice on the transducer head, noise generated from shallow depth monitoring and brief equipment power failure, both Chariton River locations provided continuous channel-bed record that demonstrated responses to hydrologic events. At both locations, the presence of bedforms was identifiable during inter-event flows, which may have provided an additive effect in the evaluation of the scour and deposition in relation to known hydrologic events. At the Chariton River near Prairie Hill (structure L-344), an RCBM was installed on the downstream side of the upstream column of pier 4. During data collection from August 21, 2007, through August 21, 2009, the channel-bed scoured as much as 13 feet from a period of record ( 78 years) peak flood event of 38,400 cubic feet per second that occurred on July 27,2008 , and had an annual exceedence probability within 0.2 
to 1 percent (500- and 100-year recurrence). At the Chariton River at Novinger (structure L-534), RCBM's were installed on the downstream side of the upstream and downstream columns of pier 7. The initial offset had to be extended horizontally at the downstream column in late June as a result of an exposed footer depicting a steady and flat representation of the channel bottom. The RCBM at the upstream column had to be extended horizontally in late October because this footer progressively became more exposed. Channel-bed record at both columns reflected as much as 3 to 5 feet of scouring as a result of hydrologic events occurring December 22, 2008, March 8, March 24, April 27, and May 16, 2009, as well as a subtle time lag between event-related scouring from the upstream to downstream monitoring locations.

RCBM's also were installed at the Mississippi River near Mehlville (structures A-1850 and A-4936) on the upstream and downstream nose of pier 12 . As a result of the complexity of the foundation of pier 12, the transducer head was positioned at a 22 degree departure from vertical to avoid interference from the footer and seal course when sounding the channel bottom. The upstream monitoring location documented channel-bed changes less than 1.5 foot over a 68 -day period of data collection before suspected damage at the upstream monitor. The downstream monitoring location documented channelbed changes as large as 5 feet over a 182-day period of data collection. Bedforms that were documented in bathymetric surveys using multibeam sonar on May 13 and July 8, 2009, indicated potential correlation to bedform movement observed June 7 through June 14, June 27 through June 30, and August 6 through August 23, 2009, as documented from the RCBM at the downstream nose.

Based on manufacturing specifications and independent depth measurements, the monitored channel bottom was typically within 0.5 foot of the physical measurement and never varied more than 1 foot during substantial hydrologic events at both Chariton River locations. For the Mississippi River location, depth measurements did not account for the 22 degree installation angle of the RCBM, required to provide adequate clearance to the channel bottom. Based on the 22 degree angle, relative distortions of bedforms or scour holes could be biased high as much as 7 percent.

\section{References Cited}

Airmar Technology Corporation, 2006, Theory of operations manual: Milford, N.H., 24 p.

Bartholoma, S.D., Kolva, J.R., and Nielsen, J.P., 2003, User's manual for the National Water Information System of the U.S. Geological Survey Automated Data Processing System (ADAPS): U.S. Geological Survey Open-File Report 2003-123, version 4.3, $407 \mathrm{p}$.
Becker, L.D., 1994, Investigation of bridge scour at selected sites on Missouri streams: U.S. Geological Survey WaterResources Investigations Report 94-4200, 40 p.

Huizinga, R.J., and Rydlund, P.H., Jr., 2004, Potential-scour assessments and estimates of scour depth using different techniques at selected bridge sites in Missouri: U.S. Geological Survey Scientific Investigations Report 2004-5213, $42 \mathrm{p}$.

Leopold, L.B., Wolman, M.G., and Miller, J.P., 1964, Fluvial processes in geomorphology: San Francisco, Calif., W.H. Freeman and Company, $522 \mathrm{p}$.

Missouri Division of Geology and Land Survey, 1979, Geologic map of Missouri: Rolla, Missouri Department of Natural Resources, scale 1:500,000.

Missouri Department of Transportation, 1977, Plans for proposed Federal Aid Interstate Highway Bridge over Mississippi River, Jefferson Barracks, Missouri: Jefferson City, Missouri State Highway Department, F.A.I. Route 270 Project EACI-1-270-9(1)84, Bridge Nos. A-1850 and A-4936.

Mueller, D.S., Landers, M.N., and Fischer, E.F., 1995, Scour measurements at bridge sites during 1993 Upper Mississippi River Basin flood: Transportation Research Record No. 1,483 , p. $47-55$.

National Oceanic and Atmospheric Administration, 2009, Coastal Services Center: Remote sensing for coastal management, accessed data August 25, 2009, at $h t t p: / / w w w . c s c$. noaa.gov/crs/rs_apps/sensors/multi_beam.htm

Pittaluga, B.M., Maffei, M., and Seminara, G., 2004, The effect of migrating bedforms on local scour around bridge piers, in Greco, M., Carravetta, A., and Della Morte, R., eds., River flow 2004: International Conference on Fluvial Hydraulics, 2d, Napoli, Italy, 2004, Proceedings: London, England, Taylor and Francis Group, v. 2, p. 575-584.

Raisz, E., 1957, Landforms of the United States physiographic map, in Pirkle, E.C., Yoho, W.H., Henry, J.A., eds., Natural landscapes of the United States (4th ed.): Dubuque, Iowa, Kendall/Hunt Publishing Company, 411 p.

Richardson, E.V., and Davis, S.R., 2001, Evaluating scour at bridges (4th ed.): U.S. Federal Highway Administration Publication FHWA NHI 01-001 Hydraulic Engineering Circular no. 18, 378 p.

U.S. Geological Survey, 2009, Overview of satellite data collection system, accessed data August 25, 2009, at http:// wa.water.usgs.gov/data/realtime/realtime_view.html. 
Publishing support provided by: Rolla Publishing Service Center

For more information concerning this publication, contact: Director, USGS Missouri Water Science Center 1400 Independence Road

Rolla, MO 65401

(573) 308-3667

Or visit the Missouri Water Science Center Web site at: http://mo.water.usgs.gov 

